\title{
Do Domestic and Foreign Exporters Differ in Learning by Exporting? Evidence from China
}

\author{
Julan $\mathrm{Du}^{\mathrm{a}}$, Yi Lu ${ }^{\mathrm{b}}$, Zhigang $\mathrm{Tao}^{\mathrm{c}}$ and Linhui $\mathrm{Yu}^{\mathrm{c}}$ \\ ${ }^{\text {a }}$ Chinese University of Hong Kong \\ b National University of Singapore \\ ${ }^{\mathrm{c}}$ University of Hong Kong
}

July 2011

\begin{abstract}
In view of the importance of intra-firm trade and export-platform FDI conducted by multinationals, we investigate how domestic firms and foreign affiliates exhibited differential impacts of export entry and exit on productivity changes. Using a comprehensive dataset from China's manufacturing industries, we employ the Olley-Pakes method to estimate firm-level TFP and the matching techniques to isolate the impacts of export participation on firm productivity. Robust evidence is obtained that domestic firms displayed significant productivity gains (losses) upon export entry (exit), whereas foreign affiliates shew no evident TFP changes. Moreover, the productivity gains for domestic export starters were more pronounced in those high and mediumtechnology industries than in low-technology ones. We explain our findings from the perspective of the technology gap theory after considering processing trade and the fragmentation of production stages in the era of globalization.
\end{abstract}

Keywords: Exporter heterogeneity, Export entry and exit, Total factor productivity, Foreign affiliates

JEL Codes: L1, D24, F14 


\section{Introduction}

Governments of many developing countries have actively pursued exportoriented industrialization polices by encouraging their manufacturing firms to export to international markets. International organizations such as United Nations and World Bank have also advised developing countries to adopt export-oriented development strategies (United Nations Trade and Investment Division, 2001; World Bank, 1987). Such policy orientation is based on the observation that exporters are more productive than non-exporters. It is believed that exporting opens up large international markets to allow firms to achieve economies of scale, and exporters with access to world markets could observe and adopt new technologies to accelerate their productivity improvement. In short, export promotion policies are predicated on the belief that exporting enhances firm productivity. Albeit a reasonable expectation, the empirical evidence is rather mixed and inconclusive. By conducting crosscountry analysis, World Bank (1993) finds that both income growth and factor productivity growth display a significant positive correlation with the share of manufactured exports in a country's total exports or gross domestic product, but leaves the direction of causality unsolved. Subsequently, a slew of studies using firm-level data find much support for self-selection, i.e., they find that exporters are more productive ex ante than non-exporters (e.g., Bernard and Jensen, 1995, 1999), which has now become part of stylized facts. In contrast, the evidence of improving productivity from exporting, i.e., learning by exporting, is much weaker. More recent studies have investigated the impacts of exporting on firm productivity by attempting to control for the self-selection problem using GMM or matching techniques. Their findings have lent support to learning by exporting, especially in transitional and developing countries (e.g., Blalock and Gertler, 2004, for the case of Indonesia; Van Biesebroeck, 2005, for the case of nine sub-Saharan African countries; De Loecker, 2007, for the case of Slovenia; Trofimenko, 2008, and Fernandes and Isgut, 2009, for the case of Colombia; Ma and Zhang, 2008, and Yang and Mallick, 2010, for the case of China). ${ }^{1}$

While some earlier studies found that learning by exporting is specific to newly established firms (e.g., Delgado, Farinas, and Ruano, 2002), firms highly exposed to export markets (e.g., Girma, Gorg and Strobl, 2004), and firms engaged in industries with low exposure to foreign firms through international trade and FDI (Greenaway and Kneller, 2008), little attension

\footnotetext{
${ }^{1}$ Studies using data from developed countries include Girma, Greenaway and Kneller (2004) and Greenaway and Kneller (2008) for UK, Serti and Tomasi (2008) for Italy, and Hahn and Park (2009) for South Korea, etc. See Greenaway and Kneller (2007) and Wagner (2007) for a survey of the relevant literature.
} 
has been paid to the distinction between domestic firms and foreign affiliates (i.e., foreign-invested firms operating in developing countries) among exporters. Built upon a combination of sunk costs and firm heterogeneity, the prevailing theoretical and empirical literature (e.g., Bernard and Jensen, 1995; Melitz, 2003; Helpman, Melitz and Yeaple, 2004; Bernard, Eaton, Jensen and Kortum, 2003) primarily emphasizes the ex ante distinction between exporters and non-exporters in terms of various characteristics like firm size, productivity, etc. As a result, exporters are mainly treated as a whole without due attention to the heterogeneity in the characteristics of exporters, particularly between domestic and foreign-invested exporters. ${ }^{2}$

In this study, we extend the examination of firm heterogeneity between exporters and non-exporters to that between domestic firms and foreign affiliates within the category of exporters in the context of developing countries. This extension is meaningful, particularly for developing economies, because of the rising popularity of intra-firm trade and export platform foreign direct investment (FDI) conducted by multinational corporations (Greenaway and Kneller, 2007). It is widely documented that along with the trend of globalization, multinationals have increasingly set up their production plants in low-cost countries such as Brazil, China, India, and Russia as their export platforms. As a result, a significant percentage of export from those low-cost countries is made by foreign affiliates in the countries. Does the impact of exporting on firm productivity differ for domestic firms as compared with foreign affiliates? This is an important question that is instrumental to our understanding of the effects of exporting on productivity. On the other hand, the possible performance differences between domestic firms and foreign affiliates in the post-exporting periods could have profound policy implications in the era of globalization when governments of developing countries strive to maintain as much economic sovereignty as possible in the face of the growing prowess of multinationals. Given that the export-oriented industrialization policy is built upon the hope that exporting enhances the productivity of indigenous firms, it is essential to analyze the potentially different effects of exporting on domestic firms and foreign affiliates. This study tries to fill in

\footnotetext{
${ }^{2}$ It is worth noting that Baldwin and $\mathrm{Gu}$ (2003) differentiated exporters by their ownership nature. Their findings reveal that in Canadian manufacturing industries, domesticcontrolled new exporters enjoyed faster growth in productivity than foreign-controlled ones. Whereas they mainly used labor productivity in their study, we employ in this paper the latest measures of TFP which has many advantages. Furthermore, we address the differences between domestic and foreign affiliate exporters in a developing country where the differences between the two are expected to be more striking. Greenaway and Kneller (2008) further addressed this issue and emphasized that foreign-owned firms significantly differ from domestic firms in their determinants of export market entry and export intensity.
} 
the void by using a large sample of data from China's manufacturing firms for the period of 1998-2005.

China offers an ideal setting to investigate learning by exporing and the possible differential impacts of exporting on firm productivity between domestic firms and foreign affiliates. Firstly, China is a fast-growing developing country with its exports rising from a meager amount of 18 billion dollars or less than $4 \%$ of its GDP in 1980 to more than 760 billion dollars or over $36 \%$ of its GDP in 2005 (Wang and Wei, 2007), and has become the largest exporting country in the world in 2010 (Lin, 2010). It is widely agreed that exporting has been an important engine of China's economic growth in the past three decades. Although the rapid growth in both aggregate output and trade implies dramatic learning by exporting among firms in China, more detailed firm-level analysis is needed to detect the positive impacts of exporting on firm productivity. Secondly, China has attracted more than US\$1,285 billion FDI (China Statistical Yearbook, 2006) between 1979 and 2005, but much of China's export has been made by foreign affiliates, not China's domestic firms (Manova and Zhang, 2008). Foreign affiliates and domestic firms are usually shown to display substantial differences in exporting behavior (Kneller and Pisu, 2004; Lu, Lu and Tao, 2008). Thus, it is important to analyze the differential impacts of exporting on productivity of domestic firms and foreign affiliates in China. Because whether it is domestic firms or foreign affiliates that benefited most from exporting in productivity is not only of academic interest that helps us understand the heterogeneity in the consequences of exporting but also of central importance to assessing the effectiveness of export promotion policies in developing countries.

Our dataset comes from annual surveys of manufacturing firms conducted by the National Bureau of Statistics of China for the period of 1998 to 2005. In measuring firm-level total factor productivity (TFP), we employ OlleyPakes (OP) method and its variants (Klette and Griliches, 1996; De Loecker, 2007; De Loecker, 2010a) to deal with the potential endogeneity issues addressed in these methods. Consistent with the literature, we find that there is self-selection in the exporting decision. In particular, it is found that among the domestic firms the more productive firms are more likely to become exporters, whereas the opposite holds for the foreign affiliates $(\mathrm{Lu}, \mathrm{Lu}$ and Tao, 2010). To isolate the impacts of exporting on firm productivity, we follow the recent literature such as De Loecker (2007) and Greenaway and Kneller (2008) to use the propensity score matching method to select control group firms. In particular, we use the nearest neighbor matching and the stratification matching methods to match new exporters with those non-exporters having similar pre-entry characteristics but remaining non-exporting. Albeit imperfect as discussed later, the propensity score method is still the most 
updated approach and is widely used in the literature.

We find that domestic firms displayed significant immediate productivity gains upon entering export markets and steadily widening cumulative productivity gains if they continued to export in the subsequent years. The TFP level of domestic export starters increased by 0.8-1.9 percentage points in the year when they began to export. This TFP premium for domestic exporters kept increasing in the subsequent years, and the cumulative TFP premium reached a level as high as 3.9-6.1\% within five years after entering export markets. However, foreign affiliates incurred immediate slower productivity growth after they started to export, but had no evident cumulative productivity changes if they continued exporting in the subsequent years. This finding is reinforced by the almost symmetric results derived from export exit. There were significant immediate and cumulative slowdown in productivity growth for domestic exporters after they stopped exporting, whereas no evident TFP changes were found for foreign affiliates after they stopped exporting. It is found that the export-led productivity gains of domestic firms were eliminated by around 1 percentage point immediately after they stopped exporting, and eliminated by as much as 2.8 percentage points four years after quitting exporting. The above results remain robust to a number of sensitivity checks, such as using alternative measures of TFP, employing an alternative matching method, focusing on a subsample of firms keeping exporting throughout the sample period, and focusing on a subsample of firms without prior experience of exporting. Furthermore, we classified all the 29 two-digit manufacturing industries into high-tech, medium-high-tech, medium-low-tech and low-tech industries according to the OECD standards. It is found that domestic export entrants in high-tech industries mostly enjoyed statistically significant immediate and cumulative TFP premia upon export entry, most of domestic export entrants in medium-high-tech industries only achieved significant cumulative TFP gains two or more years after entering into export markets, and export entrants in low-tech industries obtained no TFP gains both in the short run and in the long run. ${ }^{3}$ Finally, we offer some explanations for the empirical findings from the perspective of the technology gap theory.

This study contributes to the literature by examining the impacts of exporting on firm productivity using data from one of the largest developing countries as well as the largest exporting country in the world. To our best knowledge, several earlier studies have examined the issue in the context of

\footnotetext{
${ }^{3}$ The cross-industry differences in learning by exporting mainly lie in the timing of the effect. In terms of the magnitude of productivity gains, there is actually no clear pattern for different industries. In other words, firms engaged in high-tech industries did not necessarily achieve higher productivity gains than those in lower-tech industries.
} 
China. Kraay (1999) is one of the earliest studies on learning from exporting among China's industrial firms. More recent work includes Ma and Zhang (2008), Yang and Mallick (2010), Park et al. (2010), Luong (2011), etc. Our study differs significantly from Ma and Zhang (2008) in several respects. Firstly, they use the method of Levinsohn and Petrin (2003) to estimate firms' TFP, which relies on the availability of data on firms' value added. Albeit a good estimation method, we would lose approximately $30 \%$ of our observations if we implement this method because of the missing data on value added in years 2004 and 2005. By using the OP method, we can keep our sample as large as possible and derive more accurate estimates. Secondly, we use four variants of OP estimation methods to calculate firm-level TFP. In particular, we implemented the most updated method of De Loecker (2010a) that specifically addresses the endogenous productivity process in TFP estimation. By using these different estimation methods and comparing their results, we can improve the accuracy of our TFP estimations. Thirdly, we examine one additional important aspect of the effects of exporting on productivity, i.e., the impacts of exiting export markets on firm productivity. The findings could provide a mirror image of the impacts of export entry on firm productivity, which substantially reinforces the robustness of our conclusions. Fourthly, in terms of matching method, we use both nearest neighbor matching and stratification matching, whereas they adopt the difference-in-difference matching technique. Finally, because the proportion of input factors and input prices may well differ across industries, we follow De Loecker (2007) to estimate TFP for firms within each two-digit manufacturing industry to incorporate the cross-industry variations in the production function. Different from Yang and Mallick (2010) that study the issue based on 2340 Chinese firms in 20002 , we explore the effects of exporting on firm productivity using a much larger sample and for a longer time period. Park et al. (2010) used Asian financial crisis as an external shock to examine the impact of decreasing export growth on firm productivity. Their study focuses on the impacts of export at the intensive margin, whereas ours is at the extensive margin. Compared with Luong (2011) that examines exclusively the effects of exporting on firm productivity in the Chinese automobile industry, our study encompasses a much broader range of industries.

Our study focuses on an important source of firm heterogeneity - firm type (specifically, whether a firm is an indigenous firm or a foreign-invested firm) - and find differential impacts of exporting on domestic firms as compared with foreign affiliates. We provide a consistent explanation by resorting to the technology gap theory. We use the trajectory of productivity changes of domestic and foreign exporters and the cross-industry pattern of the effects of exporting on productivity to substantiate our interpretation of the findings 
based on the technology gap theory. The findings of the negative impacts of exit from exporting on firm productivity changes enhance the consistency and robustness of our results. To the extent that governments of developing countries aim at helping firms to improve productivity through exporting, our findings lend support to those export-oriented policies for domestic firms but not foreign affiliates.

The remainder of the paper is structured as follows. Data and empirical methodologies are described in Sections 2 and 3, respectively. The empirical findings are reported in Section 4 and their explanations are presented in Section 5. The paper concludes with Section 6 .

\section{Data}

Our data comes from the annual surveys of manufacturing firms conducted by the National Bureau of Statistics of China (NBS) for the period of 19982005. These annual surveys covered all state-owned enterprises, and those non-state-owned enterprises with annual sales of five million Chinese currency (about US\$750,000) or more. The data provides detailed information on firms' identification, operations and performance, including firm type and export status, which are essential to this study. The information contained in this dataset should be quite reliable, because the NBS has implemented standard procedures in calculating the national income account since 1995, and a strict double checking procedure has been established for large firms (Cai and Liu, 2009).

There are altogether 463,659 firms and 1,444,769 observations for the entire sample period. The number of manufacturing firms with valid export information varies from about 150,000 in the late 1990 s to over 240,000 in 2005. The percentage of China's total exports contributed by the firms in our dataset was just below $70 \%$ in the late 1990s, and was as high as $76 \%$ in 2005, indicating that our data set is highly comprehensive.

After deleting observations without reporting export information, there are 438,457 firms and 1,348,512 observations left in our sample. After a further deletion of those observations without valid information on output, factor inputs (labor, materials and capital), or investment, ${ }^{4}$ which are re-

\footnotetext{
${ }^{4}$ Annual investment of each firm is not reported directly in our dataset. But from annual information on capital stock and annual capital depreciation of each firm, we can calculate investment, $i_{i t}$, by the law of motion of capital, $k_{i, t+1}=\left(1-\delta_{i, t}\right) k_{i, t}+i_{i t}$, where $k_{i, t+1}$ is the capital stock in year $t$, and $\delta_{i, t} k_{i, t}$ is firm-level capital depreciation in year $t$. We finally obtain valid (positive) investment information for $1,198,827$ observations, which acount for $88.9 \%$ of the sample (1,348,512 observations) with export information.
} 
quired for the estimation of TFP using Olley-Pakes method, we end up with the final sample of 407,684 firms and 1,187,884 observations distributed in all twenty-nine 2-digit manufacturing industries and all thirty-one China's regions, i.e., 22 provinces, 4 province-level municipalities, and 5 minority autonomous regions in China.

In this study, we focus on the possible differential impacts of exporting on the productivity of domestic firms and foreign affiliates. The NBS provides information on whether sample firms are registered as foreign-invested enterprises. According to the "Criteria for Classifications of the Registration of Enterprise Ownership Types" issued by the National Bureau of Statistics of China, only enterprises where foreign capital accounts for no less than $25 \%$ of total registered capital are eligible for being registered as foreigninvested firms. We treat foreign-invested firms as foreign affiliates, and the rest as domestic firms. In China, when foreign investors hold minority ownership share in a foreign-invested enterprise, oftentimes it does not mean the foreign partner has small or negligible influences in shaping the enterprise's technology level, product quality standards and corporate management because the state puts restrictions on foreign ownership share in some industries (e.g., automobile, chemical products, pharmaceutical, etc.) to maintain economic sovereignty. Hence, we treat all foreign-invested enterprises as foreign affiliates.

Table 1 lists the numbers of exporters and non-exporters for both foreign affiliates and domestic firms for each of the sample years. Clearly, the number of exporters has been increasing for both types of firms over the years, indicating the growing integration of China with the world economy. What is striking is the high percentage of exporters among the foreign affiliates (at an average of $61 \%$ ) as compared with the relatively low percentage of exporters among the domestic firms (at an average of 18\%). As a result, there is not much difference in the absolute number of exporters between the two types of firms, though the total number of domestic firms is much greater than that of foreign affiliates. Given the significant contribution of foreign affiliates to China's total export and the possibly different impacts of exporting on firm productivity for foreign affiliates and domestic firms, it is thus essential to investigate separately the effects of exporting on firm productivity for these two types of firms.

Table 2 reports the number and percentage of firms that entered into the export market, those that exited from export market, and the number of net export entry for both domestic firms and foreign affiliates during the sample period. The absolute number of entrants into the export market is of similar magnitude as that of the firms that exited from the export market for domestic firms except toward the end of the sample period when there 
was a surge of new exporters possibly reflecting China's growing integration with the world economy. Similar patterns hold for foreign affiliates. As for the percentage of firms entering into the export market (measured by the number of entrants into the export market in a given year divided by the total number of non-exporters in the previous year), it fluctuated around $2 \%$ and $10 \%$ between 1999 and 2004, but surged to $5.7 \%$ and $13.8 \%$ in 2005 for domestic firms and foreign affiliates respectively. Meanwhile, the percentage of firms that exited from the export market (measured by the number of firms that exited from the export market in a given year divided by the total number of exporters in the previous year) has had slight decreases over time for both domestic firms and foreign affiliates.

In Table 3, we present in the left panel some characteristics (i.e. the various estimates of TFP level, capital stock, labor and sales) of domestic and foreign exporters and non-exporters in our unmatched sample in the preentry stage $(s=-1)$ and the post-entry stage $(s=0)$. We find that the TFP level of domestic export entrants was 3.2-5.2 percentage points higher than that of domestic non-exporters in the pre-entry stage $(\mathrm{s}=-1)$. Moreover, the size of domestic export entrants was 22, 31 and 47 percentage points larger than that of domestic non-exporters in terms of the logarithm of capital, labor and sales, respectively. This indicates that domestic export entrants are ex ente more efficient and larger than domestic non-exporters, which is consistent with the self-selection hypothesis. We further find that the TFP differences between domestic exporters and non-exporters widened to 4.68.1 percentage points in the first year of post-entry stage $(s=0)$, and the differences in firm size measured by the logarithm of capital, labor and sales also increased to 35,53 , and 58 percentage points, respectively.

Nonetheless, foreign affiliate export entrants displayed the opposite pattern in TFP level. Specifically, foreign affiliate export entrants displayed a TFP level that was 0.8-1.6 percentage points lower than that of foreign affiliate non-exporters in stage $s=-1$. The disparity continued in stage $s=0$ and reached a range of around 1.8-2.2 percentage points. Although foreign export entrants mostly have a larger size than foreign affiliate non-exporters, the differences in firm size between foreign affiliate export entrants and nonexporters are much smaller than those between domestic counterparts in both pre-entry and post-entry periods.

\section{$3 \quad$ Empirical Methodologies}

To investigate the effects of exporting on firm productivity, we need to properly estimate firm productivity and also control for the self-selection identi- 
fied in the literature. In this section, we discuss our methods for estimating firm productivity and those for matching new exporters with non-exporters in terms of their ex ante observable characteristics (i.e., finding the proper control groups for the treatment groups).

\subsection{TFP Estimation}

In this study, we adopt Olley-Pakes method (Olley and Pakes, 1996) to estimate the firm-level TFP (henceforth referred to as TFP-OP). This is because, compared with the OLS method, the TFP-OP method contains two main innovations. First, it introduces a semiparametric method to control for the simultaneity bias when estimating production functions so that we do not need to rely on instruments. Second, it controls for the selection bias in estimating production functions, which is highly relevant for a dynamic process where firms enter or exit certain industries following the changes in their productivity levels. Thus, using the TFP-OP method allows us to obtain unbiased productivity estimates.

We estimate the TFP at the 2-digit industry level to take into account the possible variations in the proportion of input factors and input prices across different industries. In addition, we include 3-digit industry dummies within each 2-digit industry to control for different sub-sectoral unobserved shocks when estimating their production function.

While using the TFP-OP method in our main analysis, we also use three variants of TFP-OP as alternative methods for the robustness checks. First, we use De Loecker (2007)'s modified TFP estimation method. As previous studies (see, for example, Bernard and Jensen, 1995, 1999) have demonstrated that exporters differ from non-exporters, De Loecker (2007) incorporates export status into the investment equation of the TFP-OP method. This method, henceforth referred to as TFP-EXP, accounts for the possible impacts of export status on firms' decisions to invest or exit the market in the face of productivity shocks.

Second, we use De Loecker (2010a)'s most updated method. According to it, the exogenous Markov productivity process in the last stage of OP procedure ignores the potential effect of exporting on future productivity, which is logically problematic for testing learning by exporting hypothesis. Thus, following his method, we allow for the impact of exporting on future productivity and include export status in previous period in the productivity evolution process. This method is henceforth called TFP-ENDEXP.

Third, as pointed out by Klette and Griliches (1996), the use of industrylevel average price rather than firm-level price leaves all the price variations across firms within the same industry uncontrolled for and leads to biased 
estimates - "omitted price bias". ${ }^{5}$ Therefore, we follow Klette and Griliches (1996) and De Loecker (2010b), and include the average sales of all firms in the industry as an additional control to address the "omitted price bias" (henceforth referred to as TFP-IND method).

See the Appendix for the technical details of these four TFP estimation methods.

\subsection{Propensity Score Matching}

In order to identify the causal impacts of exporting on productivity, we employ propensity score matching method to select control group firms. This method tries to detect some non-exporting firms that had similar tendency to export as export entrants but in fact remained non-exporting and use them as control group firms which can produce a counterfactual comparison group showing how export entrants would have performed if they had not entered export markets. Following the literature (Rosenbaum and $\mathrm{Ru}$ bin, 1983; Heckman et al., 1997; Wagner, 2002; Girma, Greenaway, and Kneller, 2004; De Loecker, 2007), we estimate the probability (i.e. propensity score) of starting to export for non-exporters based on their pre-entry observable characteristics, match export entrants with non-exporters according to propensity scores (e.g. nearest neighbor matching), and compare the differences in firm performances between export entrants and non-exporters using matched samples.

Albeit a very sharp approach, we have to admit that the propensity score method cannot provide us with an entirely satisfactory way to control for self-selection bias. First, this method is built upon a strong assumption that conditional independence is satisfied for the variable of interest, i.e., exporting decisions of non-exporters are randomly made conditional on the full set of observable characteristics. This assumption is actually untestable. Second, the propensity score is obtained on the basis of observable firm characteristics. It is possible that we have not exhausted all the observable characteristics or some unobservable characteristics have been playing a role in determining the variable of interest. Nonetheless, given the absence of a perfect method to generate a counterfactual comparison group, we follow the prevailing literature in utilizing this method, and we include as many widely used firm characteristics as possible in calculating the propensity score for starting to export, which facilitates the comparison of our findings with those of previous studies.

\footnotetext{
${ }^{5}$ Note that in our estimation, we use revenue rather than quantity of output. To recover the quantity of output, we use the industry-level average price rather than firm-level price.
} 
In the first step, we run the Probit regression of a dummy variable indicating whether a firm switched from non-exporting in year $t-1$ to exporting in year $t$ on a set of covariates in year $t-1$. Following the literature, we include a series of firm characteristics such as TFP, size of firm (in terms of capital), as well as the full set of industry dummies, region dummies and year dummies. It is documented in the literature that industrial agglomeration, skill intensity (or, technology level) and firm type are also important in predicting the probability of firm exporting. Greenaway and Kneller (2008) included the agglomeration (dummies indicating whether exporting firms are in the same industry and region) and skill intensity (measured by wages) in the Probit model. We take this into account by including three-digit industry dummies and city-level region dummies in the model. In our opinion, the inclusion of these dummies can well capture the effects of agglomeration and technology on firms' propensity to export.

Specifically, the probability for a firm to start exporting in year $t$ can be modelled as a cumulative distribution function $\phi(h()$.$) , where year t$ can be any year between 1999 and 2005, and $h($.$) is a polynomial function of covari-$ ates TFP $\left(\omega_{i, t-1}\right)$ and fixed capital $\left(k_{i, t-1}\right)$ in year $t-1 .{ }^{6}$ The polynomial function includes higher-order terms of covariates in order to satisfy the balancing hypothesis in implementing propensity score matching. In most cases, this hypothesis is satisfied when quadratic or cubic functions of $\omega_{i, t-1}$ and $k_{i, t-1}$ are used. We impose the condition of common support to ensure that the treatment firms and control firms have overlap in the propensity score matching. The predicted value derived from the Probit regression then gives each firm that did not export in year $t-1$ a score indicating its probability of entering into the export market in year $t$. The first stage analysis of the propensity score matching method reveals that total factor productivity in the previous year has positive impacts on the likelihood of exporting in the current year for China's domestic firms but negative impacts for foreign affiliates operating in China, indicating the presence of the self-selection effect into exporting market, which are consistent with the findings of $\mathrm{Lu}, \mathrm{Lu}$, and Tao (2010).

Finally, we match those firms that started entry into the export market in year $t$ (i.e., treatment group) with those firms that had similar probability of starting exporting in year $t$ but did not (i.e., control group) and estimate the effects of exporting on productivity by comparing the productivity levels of these two groups. For the main analysis, we adopt the nearest neighbor matching method, namely, for each firm that started exporting in year $t$, we

\footnotetext{
${ }^{6}$ The sample consists of those firms that appeared in at least two consecutive years but did not export in the first year.
} 
search for a non-exporting firm with the closest propensity score within the same two-digit industry. ${ }^{7}$ We use the average differences in productivity between the treatment firm group and the control firm group as a measure of the average impacts of exporting on firm productivity. As a robustness check, we also use the stratification matching method. This method involves the matching of a group of treatment firms within a range of the propensity scores for exporting with a group of control firms within the same range of the propensity scores. ${ }^{8}$ We calculate the weighted average differences in productivity between treatment firm group and control firm group as a measure of the impacts of exporting on firm productivity, where the weight is the proportion of the number of treatment firms in each block in the total number of treatment firms. (For the details of matching procedure, please refer to Appendix).

To assess the quality of our matching samples, we present in the right panel of Table 3 the characteristics of firms in pre-entry and post-entry stage using the matched sample constructed by nearest neighbor matching. We observe that the differences in TFP levels and firm size between export entrants and non-exporters in unmatched samples almost disappear in matched samples at stage $s=-1$. This demonstrates forcefully the quality of our matching sample, that is, the matching sample firms did not show significant differences from the export entrants in the year before exporting. However, in stage $\mathrm{s}=0$, domestic export entrants achieved a productivity premium of 0.8 $1.9 \%$ compared with their control firm group, whereas foreign export entrants had a productivity discount of $1-1.4 \%$ relative to their matching firms. This suggests a striking difference in the impacts of exporting on firm productivity between domestic exporters and foreign affiliate exporters.

\section{Empirical Results}

\subsection{Impacts of Export Entry on Firm Productivity}

After estimating firm productivity and identifying control firms for the treatment firms (i.e., firms that started exporting during the period of 1999-2005), we then investigate the impacts of export entry on firm productivity.

\footnotetext{
${ }^{7}$ We allow replacement during the matching process, that is, a control (non-exporting) firm can be the best match for more than one treated (exporting) firms.

${ }^{8}$ One pitfall of the stratification matching method is that it discards observations in blocks where either treated (exporting) or control (non-exporting) firms are absent. For detailed comparison of different matching methods please refer to Dehejia and Wahba (2002).
} 
Table 4 reports the estimated impacts of export entry on firm productivity for both domestic firms and foreign affiliates in China. The left panel of Table 4 presents the estimation results obtained by the nearest neighbor matching method, and the right panel shows the estimation results obtained by the stratification matching method. ${ }^{9}$ Under both matching methods, the immediate impacts of export entry on firm productivity (the difference in TFP between treatment firms and control firms in the very first year that the treatment firms started exporting) are positive and statistically significant for domestic firms (see the column under $s=0$ ). In Panel A, using TFP-OP, TFP-EXP, TFP-ENDEXP, and TFP-IND estimation methods with nearest neighbor matching, we find that domestic export entrants, relative to domestic non-exporters, achieved a productivity premium of $0.8 \%, 1.5 \%, 1.9 \%$ and $1.4 \%$, respectively, in the first year of starting to export. The stratification matching method produces similar results. Table 4 also shows the productivity gap between the treatment firms and the control firms over the years when the treatment firms continued to export whereas the control firms remained non-exporters. The productivity premium of domestic exporters over nonexporters exhibits an upward trend in the subsequent years. For example, based on the results obtained using the stratification matching method and the TFP-IND estimation method of productivity, the TFP level of domestic exporters became 1.3 percentage points higher on average than that of the control firms in the very first year of exporting. The cumulative productivity gains for the treatment firms (continuous exporters) increased to $2.5 \%, 3.8 \%$, $3.6 \%$, and $4.9 \%$ in the subsequent four years. Although we observe a slight drop in the estimated export premium from stage $2(\mathrm{~s}=2)$ to stage $3(\mathrm{~s}=3)$, the formal t-test results indicate that in most cases, especially for the results derived from the stratification matching method, the differences between the estimates in $\mathrm{s}=2$ and the ones in $\mathrm{s}=3$ are statiscally insignificant, which implies that there were no significant losses of the export premium achieved by export entrants since their entry into export markets. ${ }^{10}$ The productivity

\footnotetext{
${ }^{9}$ The maximum possible time period after a firm started exporting is six years (i.e., a firm starting exporting in 1999 and continued until the end of the sample period - 2005). However, we limit our analysis to four years as otherwise there would be substantial sample size reductions resulting in biased estimations.

${ }^{10}$ To formally test whether there are significant differences between the estimated export premium $\hat{\beta}_{s}$ derived in stage $\mathrm{s}$ and $\hat{\beta}_{s-1}$ derived in the previous stage $\mathrm{s}-1$, we use two-sample mean-comparison tests. To be specific, we can assume that $\left|\hat{\beta}_{s}-\hat{\beta}_{s-1}\right|$ has normal distribution with zero mean and stardard deviation, $\sqrt{\sigma_{s}^{2}+\sigma_{s-1}^{2}}$, based on the large sample size of $\beta_{s}$ and $\beta_{s-1}$ in our case. Rejection of this hypothesis at $95 \%$ significance level will lead to the conclusion that there are statistically significant differences between $\hat{\beta}_{s}$ and $\hat{\beta}_{s-1}$, otherwise we conclude that there is no significant difference between
} 
premium finally reaches a peak of $4.6 \%, 4.8 \%, 6.1 \%$, and $4.9 \%$ using TFP$O P, T F P-E X P, T F P-E N D E X P$, and TFP-IND estimation methods with the stratification matching method, respectively. This reflects that there are not only immediate but also cumulative productivity gains for domestic export entrants. Note that our estimated TFP premium is slightly smaller than that reported in Ma and Zhang (2008), which is probably due to different proxy variables used in the LP and OP TFP estimation frameworks. The TFP premium for exporters reported by Yang and Mallick (2010) is about 24\% in up to 2 years after starting to export, which is much larger than both that of Ma and Zhang (2008) and ours. Nonetheless, they used a much smaller sample and it is unclear how they estimated TFP.

In contrast, foreign-affiliate export starters did not exhibit productivity improvement. To our surprise, the immediate impacts of export entry on firm productivity (year $\mathrm{s}=0$ ) were negative and mostly statistically significant, which implies that foreign-affiliate export starters suffered about $1 \%$ productivity discount compared with the control group firms, i.e., foreignaffiliate non-exporters in year $\mathrm{s}=0$. This pattern is robust to most of the different ways of estimating TFP. The cumulative productivity difference became mostly positive in year $\mathrm{s}=1$ and consistently positive in later years (from $\mathrm{s}=2$ to $\mathrm{s}=4$ ) for different methods of calculating TFP and conducting propensity score matching, but most of the productivity premium estimates are unfortunately statistically insignificant. Overall, there is no evident impacts of exporting on firm productivity for foreign affiliates.

To provide a visual impression, we present in Figures 1 and 2 the trajectories of TFP levels for domestic firm export entrants, domestic firm nonexporters, foreign affiliate export entrants and foreign affiliate non-exporters based on the matched and unmatched samples of treatment firms and control firms, respectively, from the year before starting exporting $(s=-1)$ to the fourth year after exporting $(\mathrm{s}=+4)$. In Figure 1 , domestic firm export entrants displayed signficantly higher TFP levels than did domestic firm nonexporters before export entry $(\mathrm{s}=-1)$ in the unmatched sample, indicating the self-selection of more productive domestic firms to enter exporting markets. The pattern is opposite for foreign affiliates where the export entrants had lower TFP levels than did non-exporters before starting exporting. In Figure 2 , consistent with the estimation results presented in various tables, domestic firm export entrants displayed a much larger increment in productivity after starting exporting than did domestic firm non-exporters in matched sample. In contrast, foreign affiliate export starters and non-exporters did not show discernible differences in TFP levels over years.

$\hat{\beta}_{s}$ and $\hat{\beta}_{s-1}$. 


\subsection{Impacts of Export Exit on Firm Productivity}

To corroborate our findings on the impacts of export entry on firm productivity, we investigate the effects of export exit on firm productivity. The treatment group consists of export quitters, i.e., firms that had been exporting but terminated exporting later. The control group comprises firms that had similar tendency to exit export as treatment group firms in the year prior to exit but in actuality kept exporting in the subsequent years. In constructing the control groups, we also use the nearest neighbor matching and the stratification matching methods.

We then compare the productivity of export quitters with that of their control firms in order to detect the impacts of export exit on firm productivity. As shown in Table 5, the immediate impact of export exit on firm productivity (the difference in TFP between treatment firms and control firms in the very first year that the treatment firms stopped exporting) is negative and statistically significant for domestic firms.Using TFP-OP, TFP-EXP, TFP-ENDEXP, and TFP-IND estimation methods with nearest neighbor matching, we obtain an estimated productivity discount of $1 \%, 0.9 \%, 1.2 \%$, and $1 \%$, respectively, for domestic export quitters in year $\mathrm{s}=0$.

Furthermore, the cumulative impacts of export exit (the productivity gap between the treatment firms and the control firms over the years when the treatment firms remained non-exporters whereas the control firms continued exporting) were increasingly negative and mostly statistically significant for domestic firms. For example, the cumulative productivity discount for domestic export quitters reached a peak of $2.8 \%(2.7 \%)$ in year 4 if we use TFP-ENDEXP (TFP-IND) with nearest neighbor matching.

In contrast, the impacts of export exit on firm productivity for foreign affiliates is negative but statistically insignificant in the first year, but become mostly positive albeit statistically insignificant in the long term. These results are robust to the use of different methods of estimating TFP and different matching methods, and they are consistent with the results on the impacts of export entry on firm productivity in Table 4.

Figures 3 and 4 present the trajectories of TFP levels for domestic firm export quitters, domestic firm exporters, foreign affiliate export quitters and foreign affiliate exporters based on the matched and unmatched samples of treatment firms and control firms, respectively, from the year before stopping exporting $(\mathrm{s}=-1)$ to the fourth year after terminating exporting $(\mathrm{s}=+4)$. In Figure 3, domestic firm export quitters showed signficantly lower TFP levels than did domestic firm exporters before export exit $(\mathrm{s}=-1)$ in the unmatched sample, indicating the self-selection of less productive domestic exporters to quit exporting. The pattern is opposite for foreign affiliates exporters and 
exporter quitters where the latter had higher TFP levels before stopping exporting, although the differences in TFP levels between the two are not statistically significant. This pattern of self-selection of export quitters is symmetric to that of export entrants, which reinforces the findings from Figures 1 and 2. In Figure 4, consistent with the estimation results presented in various tables, domestic firm export quitters displayed a much smaller increment in productivity after stopping exporting than did domestic firm exporters in matched sample. ${ }^{11}$ In contrast, foreign affiliate export quitters and continuing exporters did not show salient differences in TFP levels over years.

It is interesting that the magnitude of the estimated productivity premium for export entry and productivity discount for export exit typically descends when we go from the TFP-ENDEXP method to the TFP-EXP, and to the TFP-OP method. This suggests that the TFP-OP method might potentially underestimate the export premium or discount as pointed out by De Loecker (2007, 2010).

\subsection{Some Robustness Tests}

Note that the results on the immediate and cumulative impacts of exporting in Table 4 are obtained from different samples. For example, the productivity gap in the third years of exporting are obtained from the sample of firms with at least three years of exporting whereas that in the second year of exporting is obtained from the sample of firms with at least two years of exporting. Because of the exit of some firms from exporting, the two samples are not identical. Therefore, as a robustness check, we restrict our analysis to those samples that do not change over time in order to prevent our productivity comparison from being contaminated by the effects of some export quitters in our sample. Specifically, for the sample of treatment firms with at least $N$ years of exporting, we look at the productivity gap between the treatment firms and control firms in the years leading to the $N$ years. Table 6 summarizes the results of this exercise, with the numbers on the diagonal being the same as those reported in Table 4. For the domestic firms, it is found that the impacts of export entry on firm productivity are all positive and almost all statistically significant. For each group of domestic exporting firms, the productivity premium is increasing in magnitude over years, suggesting an ever-expanding cumulative productivity gap induced by exporting. Comparing the productivity premium across groups of domestic exporters in

\footnotetext{
${ }^{11}$ Because all types of firms in China have experienced a trend of continuing increases in TFP level over years in this fast-growing economy, the productivity discount of export quitters is mainly reflected in a slower increment in TFP level than continuing exporters.
} 
$\mathrm{s}=0$, we find that the immediate impacts of export entry are generally larger in magnitude for those firms that had more subsequent years of exporting. However, there is no clear pattern for cross-group comparisons in later years. Meanwhile, the immediate impacts of export entry for foreign affiliates are negative and mostly insignificant, and the cumulative impacts became positive yet statistically insignificant. Clearly, the results on domestic and foreign exporters are qualitatively consistent with those reported in Table 4.

Table 7 reports the corresponding results for the impacts of export exit. Specifically, for the sample of treatment firms that had quit exporting and remained non-exporting for at least $N$ years, we look at the productivity gap between the treatment firms and control firms in the years leading to the $N$ years. For domestic firms that quit exporting for at least 1-3 years respectively (i.e., the first three rows in Panel A of Table 7), the impacts of export exit on firm productivity are all negative and mostly statistically significant in the very first year of export exit, and the impacts become widening in both magnitude and statistical significance in subsequent years. ${ }^{12}$ The productivity gap for foreign export quitters is often positive in sign although most of them are not statistically significant. In other words, the productivity decline for export quitters is confined to domestic firms. These results are qualitatively consistent with those reported in Table 4.

In our sample, there are firms that have switched from exporting to nonexporting and then back to exporting. ${ }^{13}$ Previous experience with exporting, however, may affect the impacts of (subsequent) exporting on firm productivity. On the one hand, it could reduce the effect of exporting on productivity if there is a declining marginal increment of productivity from cumulative exporting experience so that export re-starters may display smaller marginal productivity improvement than do export starters without prior exporting experience. On the other hand, it could enlarge the effect of exporting on productivity if the prior exporting experience expands the learning ability of export re-starters and magnifies the marginal productivity improvement for export re-starters. As a robustness check, we rule out this type of firms, and re-estimate the impacts of export entry on firm productivity by requiring neither treatment firms nor control firms to have any prior experience with exporting. Results obtained using three methods of TFP estimation all show that there are significant immediate and cumulative learning by exporting effects among the domestic firms, though these effects are lower than those reported in Table 4 . This provides support to our prediction of the exis-

\footnotetext{
${ }^{12}$ The results are less pronounced for those firms that quitted export for at least 4 or 5 years, presumably because of the reduction in sample size.

${ }^{13} 25 \%$ of the domestic export starters had previous experience of exporting, while the corresponding number for foreign affiliates is $37 \%$.
} 
tence of the faster learning by exporting effects among those firms with prior exporting experience (Table 8). Similarly, among the foreign affiliates, the immediate and cumulative impacts of export entry became less positive or more negative as compared with the results reported in Table 4, indicating that foreign affiliates without any prior exporting experience suffered even greater productivity discount upon entering export markets than those with some prior exporting experience.

\section{Explanations of the Results}

By examining the TFP changes upon export entry and exit, our analysis demonstrates clearly that domestic exporters learned by exporting, while foreign affiliates did not. The learning effect is presumably derived from the fact that export starters begin to acquire know-how, learn international best practices, and improve their productivity after getting in contact with foreign purchasing firms. It is argued that foreign buyers often transmit tacit and occasionally proprietary knowledge to exporting suppliers because the former wants low-cost but good-quality products (World Bank, 1993, p.320). Foreign buyers often come with models and patterns for exporting suppliers to follow and even go out to the production lines to teach workers how to do things (Rhee, Ross-Larson, and Pursell, 1984, p.41). Foreign purchasing agents may suggest ways to exporters to improve the manufacturing process (Grossman and Helpman, 1991, p.166).

This learning by exporting effect is expected to be more salient for domestic firms that started to be exposed to world technology frontier and international best practices in production and management upon exporting. According to the technology gap theory (Gerschenkron, 1962; Fagerberg, 1994), for a technologically backward country (i.e., a follower), the gap in technology level compared with the advanced countries lying on the world technological frontier (i.e., leaders) could represent "a great promise" if the backward country has accumulated a threshold level of human capital to absorb the new technology. In other words, the larger the technological gap, the more opportunities for learning for the follower, and the faster the technological catch-up that the follower could possibly achieve.

We expect that domestic firms had been equipped with lower technological capability than foreign affiliates before exporting. This is mainly because domestic firms in China had not had direct exposure to global markets and world technology frontier prior to exporting, whereas foreign affiliates had already absorbed some advanced technology and good practices in production and management from foreign investors even before exporting. According to 
the observations and theoretical predictions of Helpman, Melitz, and Yeaple (2004), there is productivity sorting for firms' exporting and FDI activities, i.e. the least productive firms exit, the less productive firms serve only the domestic market, the more productive firms serve both domestic markets and foreign markets through exporting, and the most productive firms carry out FDI in foreign countries. In this sense, the parent firms of foreign affiliates are typically lying along the technology frontier, and foreign affiliates may well have learned a great deal of cutting-edge technology and knowhow from their parent companies even prior to participating in exporting. Thus, foreign affiliates had already obtained many benefits of productivity enhancement from being linked to global markets before starting to export, and the room for further learning and improvement upon exporting is rather limited. This prediction is verified by our data. In Figure 1, we observe that foreign affiliates (both export entrants and non-exporters) started with higher TFP levels than did domestic firms (both export entrants and non-exporters) in year $\mathrm{s}=-1$ and maintained this productivity superiority throughout the window. In Figure 2, we present the TFP trajectories for these four types of firms using samples of all the treatment firms and control firms after propensity score matching. The TFP level of foreign affiliates, no matter export entrants or non-exporters, still remained higher than that of domestic firms throughout the whole period. The two figures provide us with a clear visual impression that foreign affiliate export entrants have had higher TFP levels before and after exporting than domestic export entrants. The higher initial TFP level of foreign affiliate export entrants implies a smaller room for learning by exporting based on the technology gap theory.

This explanation from the perspective of the distance to the world productivity frontier could be reinforced by the examination of the cross-industry pattern of the impacts of exporting on productivity. We estimate the effects of export entry on firm productivity within more disaggregated two-digit industries. In Table 9, we give a summary of the immediate and cumulative effects of exporting on productivity for domestic firms in two-digit industries. To better understand the relationship between export-led productivity gain and the technology level of different industries, we employ the OECD ranking of industry technology level to classify the two-digit industries into four categories, i.e., high-technology, medium-high-technology, medium-lowtechnology and low-technology groups. ${ }^{14}$ A quick look at Table 9 tells us that industries exhibit substantial heterogeneity in the statistical significance and timing of the estimated productivity gains following entry into export mar-

\footnotetext{
${ }^{14}$ The OECD classification is built on the ranking of the average R\&D intensities of different industries in the 1990s against the benchmark of aggregate OECD R\&D intensities.
} 
kets. It is striking that the industries not showing the learning-by-exporting effects are mostly low technology ones (such as food processing, and apparel and other textile products), and the remaining few are medium-low technology industries like plastic products. By contrast, most of the industries exhibiting learning-by-exporting effects are engaged in high-technology and medium-high-technology production, such as electronic and communications equipment, pharmaceuticals, etc. Furthermore, in those high-technology and medium-high-technology industries enjoying learning by exporting effect, there seems to be more evidence for cumulative productivity gains as opposed to immediate gains, which is consistent with the view that learning advanced technology takes time and continuous efforts. Nonetheless, in terms of the magnitude of productivity gains reflected in the maximum TFP gains, there is actually no clear pattern for the cross-industry differences. In other words, firms engaged in high-tech industries did not necessarily achieve higher productivity gains than those in lower-tech industries.

This pattern of heterogeneity in productivity gains for disaggregated industries in the manufacturing sector again fits well the predictions of the technology gap theory. Applied to the industry level, the technology gap theory argues that the less developed economies should grow fastest in the most technologically advanced industries where they are lagging furthest behind. In lower technology industries, the product is more standard, and production technology is more mature. As a result, production efficiency of firms in backward countries is similar to that of firms in advanced countries. Hence, it is usually in the technologically advanced industries where the size of sectoral technology gap offers the largest opportunities for diffusion of innovations devised in the developed countries (leaders) to the less developed countries (followers). Given constant exogenous productivity growth rates and technology diffusion rates in different sectors, the closing of technology gap, or catching up, would be faster in the more advanced sectors (Kubielas, 2009). Consequently, in higher technology industries, China's domestic firms lag farther behind their western counterparts in terms of technology and expertise, and therefore could learn and improve most upon their entering the international market. Thus, it is not surprising that domestic firms in the higher technology industries exhibited stronger productivity gains than those in the lower technology ones upon entering export markets.

The technology gap theory could be further extended to different production stages within the production chain. A production chain typically involves many different stages, some of which are technology intensive (e.g., manufacturing of core components containing high technology), whereas others are labor intensive (e.g., manufacturing of labor-intensive components and final assembly). Even for higher technology industries, the production chain 
includes many labor intensive stages. Applying the logic of technology gap theory, we expect that the technology gap between the leaders and followers is larger in technology-intensive production stages than in labor-intensive production stages, and engagement in a larger number of technology-intensive production stages offers ample opportunities of learning by exporting.

According to Ferrantino et al. (2008), the puzzle of high Chinese trade surplus with the U.S. in advanced technology products (ATP) could be explained by the processing trade by foreign affiliate exporters in China. They find that the processing trade ATP surplus accounts for a high percentage of Chinese ATP trade surplus with the U.S. Moreover, they find that China's ATP trade surplus with the U.S. was mainly generated by foreign affiliates, whereas domestic firms contributed only a small portion. They conclude that processing trade of foreign affiliates and the fragmentation of global production underlying it are the major reasons for the dramatic surge in China's ATP trade surplus with the U.S. ${ }^{15}$ Note, however, that, in ATP trade, the technology-intensive components are often produced in developed countries, while labor-intensive parts and especially final assembly are carried out in developing countries like China.

Consistent with their findings, our dataset also shows the dominance of foreign affiliates in the exports of higher technology products. For example, in the industry of electronic and communications equipment which is designated as a high technology industry by the OECD, foreign affiliates account for $74 \%$ of the total number of exporters and $93 \%$ of the total value of exports. These figures are largely similar to those presented in Ferrantino et al. (2008). It is reasonable to expect that in this and other higher technology industries, foreign affiliates in China are engaged mostly in processing trade and focus on the production of labor-intensive components and final assembly in China while keeping the production of the technology-intensive components in their home countries. Thus, even in those higher technology industries, the technology gap between the foreign affiliates and the world technology frontier is rather small given the labor intensive stages of production they choose to have in China. Hence there is little room for learning for foreign affiliates in these industries.

In contrast, domestic exporters, particularly those in higher technology industries, do not conduct much processing trade; instead they are engaged in the whole production chain that includes much more technology-intensive stages. It is in these technology-intensive production stages that the technol-

\footnotetext{
${ }^{15} \mathrm{In}$ another paper, $\mathrm{Lu}$ and $\mathrm{Xu}$ (2009) found that the higher proportion of processing trade conducted by foreign enterprises from OECD countries in an industry, the higher sophistication level of the industry in China, which indicates that the processing trade are usually concentrated in high-tech industries.
} 
ogy gap between domestic producers and world technology frontier is large, and leaves much space for domestic exporters to learn by exporting.

In this sense, the technology gap theory applied to production stages could deepen our understanding of the differential impacts of exporting on domestic firms and foreign affiliates by taking account of processing trade and the fragmentation of production stages in the era of globalization.

\section{Concluding Remarks}

Whether exporting promotes firm productivity is a central issue in the assessment of the effectiveness of export-promotion development policy. Unfortunately, it is an unresolved issue. Various studies in the literature have produced different findings. Though some studies such as Van Biesebroeck (2005) and De Loecker (2007) find that exporting promoted firm productivity in developing economies (e.g., Sub-Saharan countries and Slovenia), the majority of studies (e.g., Clerides, Lach, and Tybout, 1998; Bernard and Jensen, 1999; Delgado, Farinas, and Ruano, 2002) fail to detect significant learning by exporting effects, especially in industrialised countries.

In this study, we revisit the issue in the context of China, the largest developing economy and the largest exporting country. Our study sheds light on resolving the controversy over the existence of learning by exporting effects in the literature. First, we employ the latest econometric methods to estimate accurately the productivity changes for export entrants and quitters. Specifically, on the one hand, we use the Olley-Pakes method and its variants to estimate firm-level TFP by controlling for the potential endogeneity problems. On the other hand, we follow the recent literature to adopt the propensity score matching to minimize the self-selection bias in estimating the effect of export entry (exit) on firm productivity.

Second, and importantly, we take account of the firm heterogeneity among exporters, particularly the distinction between domestic firms and foreign affiliates. We find robust evidence that the productivity enhancement effect of export entry and the productivity repression effect of export exit are primarily confined to the domestic firm group. This is consistent with the prediction of the technology gap theory and the significant role played by processing trade in China's ATP exports.

Our findings that only domestic firms learned from exporting have quite general implications for our understanding of export promotion policy in developing countries. The non-existence of learning by exporting for foreign affiliates in our study may suggest that the learning by exporting effects were underestimated for developing countries in the earlier studies if foreign 
affiliates were not separated from domestic firms. Given the strong evidence of learning by exporting for domestic firms in China, we believe that export promotion policies can contribute to the efficiency enhancement of indigenous firms, and these policies could be designed to benefit more domestic firms for the attainment of the maximum policy effectiveness. This is consistent with the objective of strengthening economic sovereignty of developing countries in the era of globalization.

\section{Appendix}

\section{TFP estimation procedures}

\section{TFP-OP method}

Consider a Cobb-Douglas production function:

$$
y_{i t}=\beta_{0}+\beta_{l} l_{i t}+\beta_{m} m_{i t}+\beta_{k} k_{i t}+\omega_{i t}+u_{i t}
$$

where $y_{i t}$ is the log of output (measured by revenue) for firm $i$ in period $t ; l_{i t}, m_{i t}$,and $k_{i t}$ are the log of labor, intermediate inputs (materials) and capital stock; $\omega_{i t}$ is a productivity shock that can be observed by the firm but not by econometricians; and $u_{i t}$ is an i.i.d. shock unknown to both the firm and econometricians. Since $\omega_{i t}$ can be observed by the firm, it may simultaneously adjust its input choices according to $\omega_{i t}$ in order to optimize its profits, thus causing the simultaneity problem and the biased estimate of $\beta_{l}, \beta_{m}$ and $\beta_{k}$ using OLS estimation. Olley and Pakes (1996) addressed this issue by using investment to proxy for the unobserved productivity shock $\omega_{i t}$. Their method also addressed the selection bias issue caused by exit of low-productivity firms using survival probabilities.

Specifically, at the first stage a typical firm make decision on whether to continue operations or not based on whether their productivity is high enough for survival, the firm then decide on its level of investment $\left(i_{i t}\right)$ based on its capital stock $\left(k_{i t}\right)$, and productivity $\left(\omega_{i t}\right)$ given they continue to operate. I.e. the investment is a function of captical stock and productivity as follows:

$$
i_{i t}=f\left(k_{i t}, \omega_{i t}\right)
$$

Assuming that the investment made by the firm is montonically increasing with its productivity, $\omega_{i t}$ can be inverted into a function of $i_{i t}$ and $k_{i t}$, i.e.,

$$
\omega_{i t}=h\left(i_{i t}, k_{i t}\right)
$$


Thus the production function can be rewritten as:

$$
y_{i t}=\beta_{l} l_{i t}+\beta_{m} m_{i t}+\phi\left(i_{i t}, k_{i t}\right)+u_{i t}
$$

where $\phi\left(i_{i t}, k_{i t}\right)=\beta_{0}+\beta_{k} k_{i t}+h\left(i_{i t}, k_{i t}\right)$.

In this first step of estimation, we use a second-order polynomial $i_{i t}$ and $k_{i t}$ to approximate $\phi\left(i_{i t}, k_{i t}\right)$ and obtain the consistent estimates of $\hat{\beta}_{l}$ and $\hat{\beta}_{m}$ using OLS estimation.

In the second step, to address the survial bias problem, we estimate the survial probability of the firm $\left(P_{i t+1}\right)$ using a probit model with its dependent variable indicating whether a firm survives in the next period and independent variables $\omega_{i t}$ and $\bar{\omega}_{i t}$ (a threshold), which we proxy by a second-order polynomial of $i_{i t}$ and $k_{i t}$.

In the final step, to disentangle $\omega_{i t}$ from captical stock $k_{i t}$ in $\phi\left(i_{i t}, k_{i t}\right)$, a Markovian productivity transition process is introduced. Specifically, current productivity $\left(\omega_{i t}\right)$ is assumed to evovle from the productivity in the previous period $\left(\omega_{i t-1}\right)$ conditional on threshold of survials, i.e., $\omega_{i t}=g\left(\omega_{i t-1}, P_{i t}\right)+$ $\xi_{\iota t}$, where $\omega_{i t-1}=\hat{\phi}\left(i_{i t-1}, k_{i t-1}\right)-\beta_{k} k_{i t-1}$, and $g\left(\omega_{i t-1}, P_{i t}\right)$ is a second-order polynomial. Thus the estimate of $\hat{\beta}_{k}$ can be obtained from the following nonlinear estimation equation: .

$$
y_{i t}-\hat{\beta}_{l} l_{i t}-\hat{\beta}_{m} m_{i t}=\beta_{k} k_{i t}+g\left(\left(\hat{\phi}\left(i_{i t-1}, k_{i t-1}\right)-\beta_{k} k_{i t-1}\right), \hat{P}_{i t}\right)+u_{i t} .
$$

So far, all the estimates of interest $\left(\hat{\beta}_{l}, \hat{\beta}_{m}\right.$ and $\left.\hat{\beta}_{k}\right)$ have been estimated unbiasedly in OP framework, and we calculate the firm-level TFP-OP as follows:

$$
\hat{\omega}_{i t}=y_{i t}-\hat{\beta}_{l} l_{i t}-\hat{\beta}_{m} m_{i t}-\hat{\beta}_{k} k_{i t} \text {. }
$$

\section{TFP-EXP}

De Loecker (2007) revises the above estimation procedure by introducing the current export status (export dummy) into the OP framework to allow for different market structure and factor prices facing the firms when they make decisions about investment and exiting the market. Specifically, in the first step of TFP-EXP method, the investment becomes the function of captical stock, productivity and export status, i.e. $i_{i t}=f\left(k_{i t}, \omega_{i t}, e_{i t}\right)$, and similarly, productivity is proxied by investment, captical stock and export status, i.e. $\omega_{i t}=h\left(i_{i t}, k_{i t}, e_{i t}\right)$. Like in the TFP-OP estimation, we use second-order polynomial to proxy for $h\left(i_{i t}, k_{i t}, e_{i t}\right)$. In the second step of TFP-EXP, survival probability is assumed to also depend on the export status of a firm, 
so we add export dummy $e_{i t}$ into the probit regression model and let it interact with other terms to predict $\hat{P}_{i t}$. Similarly, the function $\hat{\phi}\left(i_{i t-1}, k_{i t-1}\right)$ in TFP-OP becomes $\hat{\phi}\left(i_{i t-1}, k_{i t-1}, e_{i t-1}\right)$ and export dummy is allowed to interact with all other terms in the polynomial function. Details of this method can be referred to in De Loecker (2007).

\section{TFP-ENDEXP}

As Ackerberg, Caves and Frazier (2006) pointed out, firms may choose variable inputs, say labor $l_{i t}$, based on their observed productivity $\omega_{i t}$, thus bias the estimate of $\beta_{l}$ in the first stage estimation using the OP framework. Therefore, they propose to estimate $\beta_{l}$ in the later stage using one more moment. De Loecker (2010a) further pointed out that the exogenous Markov productivity process in the last stage of the OP procedure ignores the potential effect of exporting on future productivity, which are logically problematic for testing learning by exporting hypothesis. Thus, following De Loecker (2010a), we allow for the impact of exporting on future productivity and include export status in the previous period in the productivity evolution process, i.e., let $\omega_{i t+1}=g\left(\omega_{i t}, e_{i t}\right)+\xi_{i t+1}$, where $e_{i t}$ is an export dummy indicating whether the firm exports or not, $\xi_{i t+1}$ is the productivity shock independent of any lagged variables (e.g. $l_{i t}$ ) and predetermined variables (e.g. $\left.k_{i t+1}\right)$.

As the first step of estimation, we first estimate the following equation:

$y_{i t}=\phi\left(i_{i t}, k_{i t}, l_{i t}, m_{i t}, e_{i t}\right)+\varepsilon_{i t}$

where $\phi\left(i_{i t}, k_{i t}, l_{i t}, m_{i t}, e_{i t}\right)=\beta_{l} l_{i t}+\beta_{m} m_{i t}+\beta_{k} k_{i t}+h\left(i_{i t}, k_{i t}, e_{i t}\right)$, in which $h\left(i_{i t}, k_{i t}, e_{i t}\right)$ is a proxy for productivity shock as in the OP framework, and $\varepsilon_{i t}$ is an i.i.d error term. We then obtain the estimate of $\phi\left(i_{i t}, k_{i t}, l_{i t}, m_{i t}, e_{i t}\right)$ for use in next step.

In the second step, we obtain $\xi_{i t+1}$ by nonparametrically regressing $\omega_{i t+1}\left(\beta_{l}, \beta_{k}\right)$ on $\left(\omega_{i t}\left(\beta_{l}, \beta_{k}\right), e_{i t}\right)$ using Kernel estimator, where $\omega_{i t+1}\left(\beta_{l}, \beta_{k}\right)=\hat{\phi}\left(i_{i t+1}, k_{i t+1}, l_{i t+1,} m_{i t+1}, e_{i t+1}\right)-$ $\beta_{l} l_{i t+1}-\beta_{m} l_{i m+1}-\beta_{k} k_{i t+1}$.

In the last step of estimation, we estimate the $\beta_{l}, \beta_{m}$ and $\beta_{k}$ using GMM relying on three moment conditions: $E\left(\xi_{i t+1} \mid l_{i t}\right)=0, E\left(\xi_{i t+1} \mid m_{i t}\right)=0$ and $E\left(\xi_{i t+1} \mid k_{i t+1}\right)=0$.

Note that compared with De Loecker (2010a), we add one more moment, i.e. $E\left(\xi_{i t+1} \mid m_{i t}\right)=0$, in the estimation process to estimate the coefficient of material input, $\beta_{m}$, because we use revenue instead of value added as measure of output. Details of this method can be found in De Loecker (2010a). 


\section{TFP-IND}

As mentioned by Klette and Griliches (1996), in order to obtain the "quantity" of inputs and output required in the production function, the revenuebased inputs and output has to be deflated by industry-level price index in the process of estimation. This approach may cause the endogeneity problem if input choices are affected by their prices as well as leave the command shocks in price and demand uncontrolled for, thus bias the estimates of production coefficients. To address this "omitted price bias" issue, we follow them to include the average sales of industries at the right hand side of estimation equation. Therefore, the production function of TFP-IND method is as follows:

$$
y_{i t}=\beta_{0}+\beta_{l} l_{i t}+\beta_{m} m_{i t}+\beta_{k} k_{i t}+\beta_{I} q_{I t}+\omega_{i t}+u_{i t}
$$

where $q_{I t}=\sum_{i \in I} s_{i t} y_{i t}$ is the weighted average output of industry $I$, and $s_{i t}$ denotes the output share of firm $i$ in industry $I$ and year $t$. We rely on this production function and standard OP framework for estimating the firm-level productivity.

Note that for all the above TFP estimation methodes, we follow De Loecker (2007) to etimate the TFPs of firms for each two-digit industry seperately to allow for the possible variations in the proportion of input factors and input prices across different industries. In addition, we include 3-digit industry dummies for each 2-digit industry to control for different subsectoral unobserved shocks when estimating their production function.

\section{Brief Description of Matching Strategies}

In the case of the nearest neighbor matching, for a treatment firm $i \in T$ where $T$ is the set of treatment firms, let $j(i)$ denote the control firm with a closest propensity score to that of firm $i$. Let $\omega_{i s}^{T}$ denote the TFP of treatment firm $i$ (with superscript $T$ standing for "treatment") in year $s$ after starting exporting, where $s=0$ stands for the year the firm just started exporting. Similarly, $\omega_{j(i) s}^{C}$ denotes the TFP of control firm $j(i)$ for treatment firm $i$ (with superscript $C$ standing for "control") in year $s$ after firm $i$ started exporting. We use the following formula to calculate the average impacts of exporting on firm productivity:

$$
\beta^{s} \equiv \frac{1}{N_{s}^{T}} \sum_{i \in T}\left(\omega_{i s}^{T}-\omega_{j(i) s}^{C}\right)
$$

where $N_{s}^{T}$ represents the number of treatment firms that have exported for $s$ years. 
In the case of the stratification matching method, a block of treatment firms within a range of the propensity scores is matched with a block of control firms within the same range of propensity scores. Let $Q$ be an integer denoting the total number of blocks of treatment and control firms. For block $q \in\{1, . ., Q\}$, let $I_{q s}$ denote the set of treatment firms that have been exporting for $s$ years (i.e., started exporting $s$ years ago), and $N_{q s}^{T}$ denote the number of firms in the set. Similarly, $J_{q s}$ denotes the set of control firms for those firms that have been exporting for $s$ years, and $N_{q s}^{C}$ denotes the number of firms in the set. We use the following formula to calculate the weighted average impacts of exporting on firm productivity where the weight is the proportion of the number of treatment firms in each block in the total number of treatment firms:

$$
\beta^{s}=\sum_{q=1}^{Q}\left(\frac{\sum_{i \in I(q)} \omega_{i s}^{T}}{N_{q s}^{T}}-\frac{\sum_{j \in J(q)} \omega_{j s}^{C}}{N_{q s}^{C}}\right) \frac{N_{q s}^{T}}{\sum_{q=1}^{Q} N_{q s}^{T}} .
$$




\section{References}

[1] Ackerberg, D., K. Caves, and G. Frazier. 2006. "Structural Identification of Production Functions." Mimeo. UCLA.

[2] Baldwin, J.R., and W. Gu. 2003. "Export-market Participation and Productivity Performance in Canadian Manufacturing." Canadian Journal of Economics 36 (3): 634-57.

[3] Bernard, A., J. Eaton, J.B. Jensen, and S. Kortum. 2003. "Plants and Productivity in International Trade." American Economic Review 93: 1268-90.

[4] Bernard, A., and J. Jensen. 1995. "Exporters, Jobs and Wages in U.S. Manufacturing, 1976-1987." Brookings Papers on Economic Activity. Microeconomics: 67-119.

[5] Bernard, A., and J. Jensen. 1999. "Exceptional Exporter Performance: Cause, Effect or Both?" Journal of International Economics 47 (1): 125.

[6] Blalock, G., and P. Gertler. 2004. "Learning from Exporting Revised in a Less Developed Setting." Journal of Development Economics 75 (2): 397-416.

[7] Branstetter, L., and N. Lardy. 2006. "China's Embrace of Globalization" NBER Working Paper w12373.

[8] Clerides, S., S. Lach, and J. Tybout. 1998. "Is Learning-by-Exporting Important? Micro-dynamic Evidence from Colombia, Mexico, and Morocco." Quarterly Journal of Economics 113 (3): 903-47.

[9] Dehejia, R., and S. Wahba. 2002. "Propensity Score-Matching Methods for Nonexperimental Causal Studies." Review of Economics and Statistics 84 (1): 151-61.

[10] Delgado, M., J. Farinas, and S. Ruano. 2002. "Firm Productivity and Export Markets: A Nonparametric Approach." Journal of International Economics 57: 397-422.

[11] De Loecker, J. 2007. "Do Export Generate Higher Productivity? Evidence from Slovenia." Journal of International Economics 73 (1): 69-98.

[12] De Loecker, J. 2010a. "A Note on Detecting Learning by Exporting." Working Paper. 
[13] De Loecker, J. 2010b. "Product Differentiation, Multi-Product Firms and Estimating the Impact of Trade Liberalization on Productivity." Forthcoming, Econometrica.

[14] Fagerberg, J. 1994. "Technology and International Differences in Growth Rates." Journal of Economic Literature 32 (3): 1147-75.

[15] Fernandes, A., and A. Isgut. 2009. "Learning-by-Exporting Effects: Are They for Real?" World Bank Policy Research Working Paper 3544.

[16] Ferrantino, M., R. Koopman, and Z. Wang. 2007. "Classification of Trade in Advanced Technology Products and its Statistics Reconciliation: The Case of China and the United States." Brookings-Tsinghua Center for Public Policy Working Paper WP20070906EN.

[17] Gerschenkron, A. 1962. Economic Backwardness in Historical Perspective. Cambridge, MA: Belknap Press.

[18] Girma, S., H. Görg, and E. Strobl. 2004. "Exports, International Investment, and Plant Performance: Evidence from A Non-parametric Test." Economics Letters 83: 317-24.

[19] Girma, S., D. Greenaway, and R. Kneller. 2004. "Does Exporting Increase Productivity? A Microeconometric Analysis of Matched Firms." Review of International Economics 12 (5): 855-66.

[20] Greenaway, D., and R. Kneller. 2007. "Firm Heterogeneity, Exporting and Foreign Direct Investment." Economic Journal 117: 134-61.

[21] Greenaway, D., and R. Kneller. 2008. "Exporting, Productivity and Agglomeration." European Economic Review 52 (5): 919-39.

[22] Grossman, G., and E. Helpman. 1991. Innovation and Growth in the World Economy. MIT Press, Cambridge.

[23] Hahn, C., and C. Park. 2009. "Learning-by-Exporting in Korean Manufacturing: A Plant-level Analysis." ERIA Discussion Paper Series.

[24] Heckman, J., H. Ichimura, and P. Todd. 1997. "Matching as An Econometric Evaluation Estimator." Review of Economic Studies 65 (2): 26194.

[25] Helpman, E., M. Melitz, and S. Yeaple. 2004. "Export versus FDI with Heterogeneous Firms." American Economic Review 94 (1): 300-16. 
[26] Imbens, G. 2000. "The Role of Propensity Score in Estimating DoseResponse Functions." Biometrika 87 (3): 706-10.

[27] Klette, T., and Z. Griliches. 1996. "The Inconsistency of Common Scale Estimators When Output Prices are Unobserved and Endogenous." Journal of Applied Econometrics 11 (4): 343-61.

[28] Kneller, R., and M. Pisu. 2004. "Export-oriented FDI in the UK." $O x$ ford Review of Economic Policy 20 (3): 424-39.

[29] Kraay, A. 1999. "Exports and Economic Performance: Evidence from a Panel of Chinese Enterprises." Revne d'Economie du Developpement 2: 183-207.

[30] Kubielas, S. 2009. "Technology Gap Approach to Industrial Dynamics and Sectoral Systems of Innovation in Transforming CEE Economies." Working paper, Warsaw University.

[31] Levinsohn, J., and A. Petrin. 2003. "Estimating Production Functions Using Inputs to Control for Unobservables." Review of Economics Studies, 70 (2): 317-41.

[32] Levinsohn, J., and M. Melitz. 2006. "Productivity in a Differentiated Products Market Equilibrium." Mimeo.

[33] Lin, Justin Y. 2010. "The China Miracle Demystified." Speech in the Econometric Society World Congress. August 19 2010. Shanghai.

[34] Lin, P., Z. Liu, and Y. Zhang. 2009. "Do Chinese Domestic Firms Benefit from FDI Inflow? Evidence of Horizontal and Vertical Spillovers." China Economic Review 20 (4): 677-91.

[35] Lu, J., and B. Xu. 2009. "Foreign Direct Investment, Processing Trade, and the Sophistication of China's Exports." China Economic Review 20 (3): 425-39.

[36] Lu, J., Y. Lu, and Z. Tao. 2010. "Exporting Behavior of Foreign Affiliates: Theory and Evidence." Journal of International Economics Forthcoming.

[37] Luong, Tuan A. 2011. "Is there Learning by Exporting? Evidence from the Automobile Industrial in China." Working Paper.

[38] Ma, Y., and Y. Zhang. 2008. "What's Different about New Exporters? Evidence from Chinese Manufacturing Firms." Working Paper. 
[39] Manova, K., and Z. Zhang. 2008. "China's Exporters and Importers: Firms, Products, and Trade Partners." NBER Working Paper w15249.

[40] Melitz, M. 2003. "The Impact of Trade on Intra-industry Reallocations and Aggregate Industry Productivity." Econometrica 71 (6): 1695-725.

[41] Olley, S., and A. Pakes. 1996. "The Dynamics of Productivity in the Telecommunications Equipment Industry." Econometrica 64 (6): 126398.

[42] Park, A., D. Yang, X. Shi, and Y. Jiang. 2010. "Exporting and Firm Performance: Chinese Exporters and the Asian Financial Crisis." Review of Economics and Statistics 92: 822-42.

[43] Pavcnik, N. 2002. "Trade Liberalization, Exit, and Productivity Improvements: Evidence from Chilean Plants." Review of Economic Studies 69: 245-76.

[44] Rhee, Y., B. Ross-Larson, and G. Pursell. 1984. Korea's Competitive Edge: Managing the Entry into World Markets. Baltimore: Johns Hopkins University Press.

[45] Rosenbaum, P., and D. Rubin. 1983. "The Central Role of the Propensity Score in Observational Studies for Causal Effects." Biometrica, 70 (1): 41-55.

[46] Serti, F., and C. Tomasi. 2008. "Self-selection and Post-Entry Effects of Exports: Evidence from Italian Manufacturing Firms." Review of World Economics 144 (4): 660-94.

[47] Trofimenko, N. 2008. "Learning by Exporting: Does It Matter Where One Learns? Evidence from Colombian Manufacturing Firms." Economic Development and Cultural Change, 56 (4): 871-894.

[48] United Nation Trade and Investment Division. 2001. "Export Promotion for Economies in Transition: Central Asia and South-Caucasus, Studies in Trade and Investment No.45." United Nations. New York.

[49] Van Biesebroeck, J. 2005. "Exporting Raises Productivity in SubSaharan African Manufacturing Firms." Journal of International Economics 67 (2): 373-91.

[50] Wagner, J. 2002. "The Causal Effect of Exports on Firm Size and Labor Productivity: First Evidence from a Matching Approach." Economics Letters 77 (2): 287-92. 
[51] Wagner, J. 2007. "Exports and Productivity: A Survey of the Evidence from Firm Level Data." The World Economy 30 (1): 60-82.

[52] Wang, Z., and S. Wei. 2007. "The Rising Sophistication of China's Exports: Assessing the Roles of Processing Trade, Foreign Invested Firms, Human Capital, and Government Policies." NBER Working Paper w13771.

[53] World Bank. 1987. "World Development Report 1987: Barriers to Adjustment and Growth in the World Economy; Industrialization and Foreign Trade; World Development Indicators." Oxford University Press, New York.

[54] World Bank. 1993. "The East Asian Miracle: Economic Growth and Public Policy." Washington D.C. World Bank.

[55] World Bank. 1997. "World Development Report 1997: The State in a Changing World." Oxford University Press. New York.

[56] Yang, Y., and S. Mallick. 2010. "Export Premium, Self-selection and Learning-by-Exporting: Evidence from Chinese Matched Firms." The World Economy 33 (10): 1218-40. 
Table 1. Exporters and non-exporters in China's manufacturing industries (1998-2005)

\begin{tabular}{cccccccc} 
& \multicolumn{3}{c}{ Domestic firms } & & \multicolumn{3}{c}{ Foreign affiliates } \\
\cline { 2 - 3 } Year & $\begin{array}{c}\text { Number of } \\
\text { exporters }\end{array}$ & $\begin{array}{c}\text { Number of } \\
\text { non-exporters }\end{array}$ & $\begin{array}{c}\text { Percentage of } \\
\text { exporters }\end{array}$ & & $\begin{array}{c}\text { Number of } \\
\text { exporters }\end{array}$ & $\begin{array}{c}\text { Number of } \\
\text { non-exporters }\end{array}$ & $\begin{array}{c}\text { Percentage of } \\
\text { exporters }\end{array}$ \\
\hline 1998 & 19603 & 103859 & $16 \%$ & & 15453 & 10640 & $59 \%$ \\
1999 & 18876 & 101663 & $16 \%$ & & 15457 & 10970 & $58 \%$ \\
2000 & 19991 & 97378 & $17 \%$ & & 16818 & 10969 & $61 \%$ \\
2001 & 21524 & 104184 & $17 \%$ & & 18912 & 12049 & $61 \%$ \\
2002 & 24270 & 108495 & $18 \%$ & & 20683 & 13282 & $61 \%$ \\
2003 & 26868 & 116065 & $19 \%$ & & 23656 & 14366 & $62 \%$ \\
2004 & 23613 & 96439 & $20 \%$ & & 23611 & 13584 & $63 \%$ \\
2005 & 38519 & 152586 & $20 \%$ & & 34072 & 20057 & $63 \%$ \\
Average & 24158 & 110084 & $18 \%$ & & 21083 & 13240 & $61 \%$ \\
\hline
\end{tabular}


Table 2. Number and percentage of export entry/exit in China's manufacturing industries (1999-2005)

\begin{tabular}{|c|c|c|c|c|c|c|c|}
\hline \multirow[b]{2}{*}{ Year } & \multicolumn{3}{|c|}{ Export entry } & \multicolumn{3}{|c|}{ Export exit } & \multirow[b]{2}{*}{$\begin{array}{l}\text { Net export } \\
\text { entry* }\end{array}$} \\
\hline & $\begin{array}{l}\text { Number of } \\
\text { export entry }\end{array}$ & $\begin{array}{c}\text { Number of } \\
\text { non-exporters in } \\
\text { previous year }\end{array}$ & $\begin{array}{c}\text { Percentage } \\
\text { of export } \\
\text { entry } \\
\end{array}$ & $\begin{array}{l}\text { Number of } \\
\text { export exit }\end{array}$ & $\begin{array}{l}\text { Number of } \\
\text { exporters in } \\
\text { previous year }\end{array}$ & $\begin{array}{c}\text { Percentage } \\
\text { of export } \\
\text { exit } \\
\end{array}$ & \\
\hline & \multicolumn{7}{|c|}{ Panel A: Domestic firms } \\
\hline 1999 & 2181 & 103859 & $2.1 \%$ & 2505 & 19603 & $12.8 \%$ & -324 \\
\hline 2000 & 2231 & 101663 & $2.2 \%$ & 1918 & 18876 & $10.2 \%$ & 313 \\
\hline 2001 & 1801 & 97378 & $1.8 \%$ & 1859 & 19991 & $9.3 \%$ & -58 \\
\hline 2002 & 2857 & 104184 & $2.7 \%$ & 2131 & 21524 & $9.9 \%$ & 726 \\
\hline 2003 & 2668 & 108495 & $2.5 \%$ & 2213 & 24270 & $9.1 \%$ & 455 \\
\hline 2004 & 2378 & 116065 & $2.0 \%$ & 2262 & 26868 & $8.4 \%$ & 116 \\
\hline \multirow[t]{2}{*}{2005} & 5490 & 96439 & $5.7 \%$ & 2742 & 23613 & $11.6 \%$ & 2748 \\
\hline & \multicolumn{7}{|c|}{ Panel B: Foreign affiliates } \\
\hline 1999 & 1036 & 10640 & $9.7 \%$ & 1087 & 15453 & $7.0 \%$ & -51 \\
\hline 2000 & 1237 & 10970 & $11.3 \%$ & 981 & 15457 & $6.3 \%$ & 256 \\
\hline 2001 & 1096 & 10969 & $10.0 \%$ & 993 & 16818 & $5.9 \%$ & 103 \\
\hline 2002 & 1297 & 12049 & $10.8 \%$ & 1196 & 18912 & $6.3 \%$ & 101 \\
\hline 2003 & 1297 & 13282 & $9.8 \%$ & 1013 & 20683 & $4.9 \%$ & 284 \\
\hline 2004 & 1253 & 14366 & $8.7 \%$ & 1032 & 23656 & $4.4 \%$ & 221 \\
\hline 2005 & 1881 & 13584 & $13.8 \%$ & 1405 & 23611 & $6.0 \%$ & 476 \\
\hline
\end{tabular}

Notes: *: exporters that begin to export in the first of establishment are not counted in this statistics. 
Table 3. Firm characteristics of export entrants by exporting status and ownership in unmatched and matched samples

\begin{tabular}{|c|c|c|c|c|c|c|c|c|c|c|c|c|}
\hline & \multicolumn{6}{|c|}{ Unmatched sample } & \multicolumn{6}{|c|}{ Matched sample } \\
\hline & \multicolumn{3}{|c|}{ Pre-entry stage $(\mathrm{S}=-1)$} & \multicolumn{3}{|c|}{ Post-entry stage $(\mathrm{S}=0)$} & \multicolumn{3}{|c|}{ Pre-entry stage $(\mathrm{S}=-1)$} & \multicolumn{3}{|c|}{ Post-entry stage $(\mathrm{S}=0)$} \\
\hline & $\begin{array}{c}\text { Non- } \\
\text { exporters }\end{array}$ & $\begin{array}{l}\text { Export } \\
\text { entrant }\end{array}$ & Diff. & $\begin{array}{c}\text { Non- } \\
\text { exporters }\end{array}$ & $\begin{array}{l}\text { Export } \\
\text { entrant }\end{array}$ & Diff. & $\begin{array}{c}\text { Non- } \\
\text { exporters }\end{array}$ & $\begin{array}{l}\text { Export } \\
\text { entrant }\end{array}$ & Diff. & $\begin{array}{c}\text { Non- } \\
\text { exporters }\end{array}$ & $\begin{array}{l}\text { Export } \\
\text { entrant }\end{array}$ & Diff. \\
\hline & \multicolumn{12}{|c|}{ Panel A: Domestic firms } \\
\hline TFP-OP & 1.113 & 1.145 & $0.032 * * *$ & 1.155 & 1.201 & $0.046 * * *$ & 1.145 & 1.145 & 0.000 & 1.190 & 1.198 & $0.008 * * *$ \\
\hline TFP-EXP & 1.118 & 1.156 & $0.038 * * *$ & 1.164 & 1.225 & $0.061 * * *$ & 1.157 & 1.156 & -0.001 & 1.209 & 1.224 & $0.015^{* * *}$ \\
\hline TFP-ENDEXP & 1.509 & 1.561 & $0.052 * * *$ & 1.548 & 1.629 & $0.081 * * *$ & 1.564 & 1.562 & -0.002 & 1.608 & 1.627 & $0.019 * * *$ \\
\hline TFP-IND & 1.113 & 1.148 & $0.035 * * *$ & 1.156 & 1.215 & $0.059 * * *$ & 1.147 & 1.148 & 0.000 & 1.199 & 1.213 & $0.014 * * *$ \\
\hline $\log ($ Capital $)$ & 8.37 & 8.59 & $0.22 * *$ & 8.39 & 8.74 & $0.35 * *$ & 8.58 & 8.59 & 0.01 & 8.66 & 8.72 & $0.06 *$ \\
\hline $\log ($ Labor $)$ & 4.82 & 5.13 & $0.31 * * *$ & 4.89 & 5.42 & $0.53 * * *$ & 5.11 & 5.13 & 0.02 & 5.23 & 5.42 & $0.19 * * *$ \\
\hline \multirow[t]{2}{*}{ Log(Sales) } & 9.67 & 10.14 & $0.47 * * *$ & 9.79 & 10.37 & $0.58 * * *$ & 10.11 & 10.14 & 0.03 & 10.21 & 10.38 & $0.17 * *$ \\
\hline & \multicolumn{12}{|c|}{ Panel B: Foreign affiliates } \\
\hline TFP-OP & 1.188 & 1.180 & $-0.008 *$ & 1.246 & 1.241 & -0.005 & 1.179 & 1.180 & 0.001 & 1.244 & 1.241 & -0.003 \\
\hline TFP-EXP & 1.197 & 1.185 & $-0.012 * *$ & 1.262 & 1.244 & $-0.018^{* *}$ & 1.185 & 1.185 & 0.000 & 1.253 & 1.242 & $-0.011^{* *}$ \\
\hline TFP-ENDEXP & 1.604 & 1.588 & $-0.016^{* * *}$ & 1.665 & 1.642 & $-0.022 * * *$ & 1.589 & 1.588 & -0.001 & 1.655 & 1.641 & $-0.014 * *$ \\
\hline TFP-IND & 1.196 & 1.183 & $-0.013 * *$ & 1.258 & 1.263 & $-0.018 *$ & 1.181 & 1.183 & 0.002 & 1.253 & 1.263 & $-0.010^{*}$ \\
\hline Log(Capital) & 9.07 & 8.96 & -0.10 & 9.08 & 9.21 & $0.13 *$ & 8.96 & 8.96 & 0.00 & 9.03 & 9.21 & $0.18 * *$ \\
\hline Log(Labor) & 4.77 & 5.01 & $0.24 * * *$ & 4.84 & 5.32 & $0.48 * * *$ & 5.03 & 5.01 & -0.02 & 5.11 & 5.32 & $0.21 * * *$ \\
\hline Log(Sales) & 10.15 & 10.33 & $0.18 *$ & 10.21 & 10.51 & $0.30 * *$ & 10.32 & 10.33 & 0.01 & 10.38 & 10.51 & $0.13 *$ \\
\hline
\end{tabular}

TFP-EXP, TFP-EMDEXP, and TFP-IND. *, **, and *** denote statistical significance at $10 \%, 5 \%$, and $1 \%$ level, respectively. 
Table 4. Impacts of export entry on firm productivity

\begin{tabular}{|c|c|c|c|c|c|c|c|c|c|c|c|}
\hline & & \multicolumn{5}{|c|}{ Nearest Neighbor Matching } & \multicolumn{5}{|c|}{ Stratification Matching } \\
\hline & & $\mathrm{s}=0$ & $\mathrm{~s}=1$ & $\mathrm{~s}=2$ & $s=3$ & $\mathrm{~s}=4$ & $\mathrm{~s}=0$ & $\mathrm{~s}=1$ & $\mathrm{~s}=2$ & $\mathrm{~s}=3$ & $s=4$ \\
\hline & & \multicolumn{10}{|c|}{ Panel A: Domestic firms } \\
\hline TFP-OP & $\beta$ & $\begin{array}{c}0.008 * * * \\
(0.003)\end{array}$ & $\begin{array}{c}0.025 * * * \\
(0.004)\end{array}$ & $\begin{array}{c}0.035 * * * \\
(0.006)\end{array}$ & $\begin{array}{c}0.030 * * * \\
(0.007)\end{array}$ & $\begin{array}{c}0.042 * * * \\
(0.010)\end{array}$ & $\begin{array}{c}0.014 * * * \\
(0.002)\end{array}$ & $\begin{array}{c}0.025 * * * \\
(0.003)\end{array}$ & $\begin{array}{c}0.039 * * * \\
(0.005)\end{array}$ & $\begin{array}{c}0.036 * * * \\
(0.006)\end{array}$ & $\begin{array}{c}0.046 * * * \\
(0.009)\end{array}$ \\
\hline TFP-EXP & $\beta$ & $\begin{array}{c}0.015 * * * \\
(0.003)\end{array}$ & $\begin{array}{c}0.027 * * * \\
(0.004)\end{array}$ & $\begin{array}{c}0.044 * * * \\
(0.006)\end{array}$ & $\begin{array}{c}0.030 * * * \\
(0.007)\end{array}$ & $\begin{array}{c}0.039 * * * \\
(0.010)\end{array}$ & $\begin{array}{c}0.014 * * * \\
(0.002)\end{array}$ & $\begin{array}{c}0.026 * * * \\
(0.003)\end{array}$ & $\begin{array}{c}0.040 * * * \\
(0.004)\end{array}$ & $\begin{array}{c}0.038 * * * \\
(0.006)\end{array}$ & $\begin{array}{c}0.048 * * * \\
(0.009)\end{array}$ \\
\hline TFP-ENDEXP & $\beta$ & $\begin{array}{c}0.019 * * * \\
(0.004)\end{array}$ & $\begin{array}{c}0.034 * * * \\
(0.005)\end{array}$ & $\begin{array}{c}0.054 * * * \\
(0.007)\end{array}$ & $\begin{array}{c}0.041 * * * \\
(0.008)\end{array}$ & $\begin{array}{c}0.049 * * * \\
(0.012)\end{array}$ & $\begin{array}{c}0.017 * * * \\
(0.003)\end{array}$ & $\begin{array}{c}0.032 * * * \\
(0.004)\end{array}$ & $\begin{array}{c}0.048 * * * \\
(0.005)\end{array}$ & $\begin{array}{c}0.046 * * * \\
(0.007)\end{array}$ & $\begin{array}{c}0.061 * * * \\
(0.010)\end{array}$ \\
\hline TFP-IND & $\beta$ & $\begin{array}{c}0.014 * * * \\
(0.003)\end{array}$ & $\begin{array}{c}0.024 * * * \\
(0.004)\end{array}$ & $\begin{array}{c}0.040 * * * \\
(0.006)\end{array}$ & $\begin{array}{c}0.035 * * * \\
(0.007)\end{array}$ & $\begin{array}{c}0.047 * * * \\
(0.011)\end{array}$ & $\begin{array}{c}0.013 * * * \\
(0.002)\end{array}$ & $\begin{array}{c}0.025 * * * \\
(0.003)\end{array}$ & $\begin{array}{c}0.038 * * * \\
(0.004)\end{array}$ & $\begin{array}{c}0.036 * * * \\
(0.006)\end{array}$ & $\begin{array}{c}0.049 * * * \\
(0.009)\end{array}$ \\
\hline \# of treatment firms & & 18917 & 7589 & 4206 & 2381 & 1215 & 18917 & 7589 & 4206 & 2381 & 1215 \\
\hline \# of control firms & & 17998 & 7306 & 4058 & 2290 & 1154 & 415523 & 251152 & 155328 & 94704 & 51299 \\
\hline & & \multicolumn{10}{|c|}{ Panel B: Foreign Affiliates } \\
\hline TFP-OP & $\beta$ & $\begin{array}{l}-0.003 \\
(0.005)\end{array}$ & $\begin{array}{c}0.001 \\
(0.006)\end{array}$ & $\begin{array}{c}0.011 \\
(0.008)\end{array}$ & $\begin{array}{c}0.003 \\
(0.011)\end{array}$ & $\begin{array}{c}0.016 \\
(0.015)\end{array}$ & $\begin{array}{c}-0.007 * * \\
(0.003)\end{array}$ & $\begin{array}{c}0.001 \\
(0.004)\end{array}$ & $\begin{array}{c}0.008 \\
(0.006)\end{array}$ & $\begin{array}{c}0.004 \\
(0.007)\end{array}$ & $\begin{array}{c}0.019 \\
(0.013)\end{array}$ \\
\hline TFP-EXP & $\beta$ & $\begin{array}{c}-0.011 * * \\
(0.005)\end{array}$ & $\begin{array}{c}0.001 \\
(0.007)\end{array}$ & $\begin{array}{c}0.007 \\
(0.009)\end{array}$ & $\begin{array}{c}0.001 \\
(0.011)\end{array}$ & $\begin{array}{c}0.023 \\
(0.015)\end{array}$ & $\begin{array}{l}-0.006^{*} \\
(0.003)\end{array}$ & $\begin{array}{c}0.003 \\
(0.005)\end{array}$ & $\begin{array}{c}0.009 \\
(0.006)\end{array}$ & $\begin{array}{c}0.007 \\
(0.007)\end{array}$ & $\begin{array}{c}0.025 \\
(0.014)\end{array}$ \\
\hline TFP-ENDEXP & $\beta$ & $\begin{array}{c}-0.014 * * \\
(0.006)\end{array}$ & $\begin{array}{c}0.002 \\
(0.007)\end{array}$ & $\begin{array}{c}0.005 \\
(0.009)\end{array}$ & $\begin{array}{c}0.008 \\
(0.012)\end{array}$ & $\begin{array}{c}0.027 \\
(0.016)\end{array}$ & $\begin{array}{c}-0.009 * * \\
(0.004)\end{array}$ & $\begin{array}{c}0.005 \\
(0.006)\end{array}$ & $\begin{array}{c}0.009 \\
(0.008)\end{array}$ & $\begin{array}{c}0.013 \\
(0.009)\end{array}$ & $\begin{array}{c}0.026 \\
(0.015)\end{array}$ \\
\hline TFP-IND & $\beta$ & $\begin{array}{l}-0.010 * \\
(0.005)\end{array}$ & $\begin{array}{l}-0.002 \\
(0.007)\end{array}$ & $\begin{array}{c}0.019 * * \\
(0.008)\end{array}$ & $\begin{array}{c}0.009 \\
(0.011)\end{array}$ & $\begin{array}{l}0.026 * \\
(0.014)\end{array}$ & $\begin{array}{c}-0.007 * * \\
(0.003)\end{array}$ & $\begin{array}{c}0.003 \\
(0.004)\end{array}$ & $\begin{array}{c}0.009 \\
(0.006)\end{array}$ & $\begin{array}{c}0.006 \\
(0.007)\end{array}$ & $\begin{array}{c}0.029 * * \\
(0.013)\end{array}$ \\
\hline \# of treatment firms & & 8670 & 4512 & 2932 & 1924 & 1176 & 8670 & 4512 & 2932 & 1924 & 1174 \\
\hline \# of control firms & & 7413 & 3865 & 2494 & 1566 & 914 & 48493 & 29169 & 18502 & 11465 & 6573 \\
\hline
\end{tabular}


Table 5. Impacts of export exit on firm productivity

\begin{tabular}{|c|c|c|c|c|c|c|c|c|c|c|c|}
\hline & & \multicolumn{5}{|c|}{ Nearest Neighbor Matching } & \multicolumn{5}{|c|}{ Stratification Matching } \\
\hline & & $\mathrm{s}=0$ & $\mathrm{~s}=1$ & $\mathrm{~s}=2$ & $\mathrm{~s}=3$ & $\mathrm{~s}=4$ & $\mathrm{~s}=0$ & $\mathrm{~s}=1$ & $\mathrm{~s}=2$ & $\mathrm{~s}=3$ & $\mathrm{~s}=4$ \\
\hline & & \multicolumn{10}{|c|}{ Panel A: Domestic firms } \\
\hline TFP-OP & $\beta$ & $\begin{array}{c}-0.010 * * * \\
(0.003)\end{array}$ & $\begin{array}{c}-0.014 * * \\
(0.004)\end{array}$ & $\begin{array}{l}-0.011 * \\
(0.006)\end{array}$ & $\begin{array}{l}-0.009 \\
(0.008)\end{array}$ & $\begin{array}{l}-0.004 \\
(0.012)\end{array}$ & $\begin{array}{c}-0.010^{* * *} \\
(0.002)\end{array}$ & $\begin{array}{c}-0.012 * * * \\
(0.003)\end{array}$ & $\begin{array}{l}-0.006 \\
(0.004)\end{array}$ & $\begin{array}{c}-0.018 * * * \\
(0.006)\end{array}$ & $\begin{array}{c}-0.025 * * * \\
(0.008)\end{array}$ \\
\hline TFP-EXP & $\beta$ & $\begin{array}{c}-0.009 * * * \\
0.003\end{array}$ & $\begin{array}{c}-0.014 * * \\
(0.005)\end{array}$ & $\begin{array}{c}-0.013 * * \\
(0.006)\end{array}$ & $\begin{array}{c}-0.020 * * \\
(0.009)\end{array}$ & $\begin{array}{c}-0.021 * * \\
(0.011)\end{array}$ & $\begin{array}{c}-0.010 * * * \\
(0.002)\end{array}$ & $\begin{array}{c}-0.012 * * * \\
(0.003)\end{array}$ & $\begin{array}{l}-0.007 \\
(0.004)\end{array}$ & $\begin{array}{c}-0.017 * * \\
(0.006)\end{array}$ & $\begin{array}{c}-0.024 * * * \\
(0.008)\end{array}$ \\
\hline TFP-ENDEXP & $\beta$ & $\begin{array}{c}-0.012 * * * \\
(0.004)\end{array}$ & $\begin{array}{c}-0.018 * * * \\
(0.006)\end{array}$ & $\begin{array}{c}-0.016^{* *} \\
(0.007)\end{array}$ & $\begin{array}{c}-0.025 * * * \\
(0.009)\end{array}$ & $\begin{array}{c}-0.028 * * \\
(0.012)\end{array}$ & $\begin{array}{c}-0.011 * * * \\
(0.003)\end{array}$ & $\begin{array}{c}-0.016^{* * *} \\
(0.004)\end{array}$ & $\begin{array}{c}-0.012 * * \\
(0.005)\end{array}$ & $\begin{array}{c}-0.018 * * \\
(0.008)\end{array}$ & $\begin{array}{c}-0.027 * * * \\
(0.010)\end{array}$ \\
\hline TFP-IND & $\beta$ & $\begin{array}{c}-0.010 \text { *** } \\
(0.003)\end{array}$ & $\begin{array}{c}-0.018 * * * \\
(0.005)\end{array}$ & $\begin{array}{l}-0.007 \\
(0.006)\end{array}$ & $\begin{array}{c}-0.023 * * * \\
0.009\end{array}$ & $\begin{array}{l}-0.027 * * * \\
(0.011)\end{array}$ & $\begin{array}{c}-0.010 * * * \\
(0.002)\end{array}$ & $\begin{array}{c}-0.012 * * * \\
(0.003)\end{array}$ & $\begin{array}{l}-0.007 \\
(0.005)\end{array}$ & $\begin{array}{c}-0.019 * * * \\
(0.006)\end{array}$ & $\begin{array}{c}-0.025 * * * \\
(0.008)\end{array}$ \\
\hline$\#$ of treatment firms & & 14943 & 6741 & 3644 & 2082 & 1162 & 14942 & 6740 & 3643 & 2082 & 1162 \\
\hline \# of control firms & & 13144 & 6083 & 3317 & 1902 & 1029 & 96509 & 59128 & 36394 & 21898 & 12099 \\
\hline & & \multicolumn{10}{|c|}{ Panel B: Foreign Affiliates } \\
\hline TFP-OP & $\beta$ & $\begin{array}{l}-0.007 \\
(0.005)\end{array}$ & $\begin{array}{c}0.009 \\
(0.007)\end{array}$ & $\begin{array}{l}0.021 * \\
(0.011)\end{array}$ & $\begin{array}{c}0.013 \\
(0.014)\end{array}$ & $\begin{array}{c}-0.017 \\
(0.019)\end{array}$ & $\begin{array}{r}-0.006 \\
(0.003)\end{array}$ & $\begin{array}{c}0.005 \\
(0.005)\end{array}$ & $\begin{array}{c}0.004 \\
(0.007)\end{array}$ & $\begin{array}{c}0.019 \\
(0.010)\end{array}$ & $\begin{array}{l}-0.001 \\
(0.014)\end{array}$ \\
\hline TFP-EXP & $\beta$ & $\begin{array}{l}-0.009 \\
(0.006)\end{array}$ & $\begin{array}{l}-0.003 \\
(0.008)\end{array}$ & $\begin{array}{l}-0.003 \\
(0.010)\end{array}$ & $\begin{array}{c}0.022 \\
(0.014)\end{array}$ & $\begin{array}{l}-0.009 \\
(0.019)\end{array}$ & $\begin{array}{l}-0.007 \\
(0.004)\end{array}$ & $\begin{array}{c}0.005 \\
(0.005)\end{array}$ & $\begin{array}{c}0.004 \\
(0.007)\end{array}$ & $\begin{array}{c}0.009 \\
(0.010)\end{array}$ & $\begin{array}{l}-0.002 \\
(0.014)\end{array}$ \\
\hline TFP-ENDEXP & $\beta$ & $\begin{array}{l}-0.010 \\
(0.007)\end{array}$ & $\begin{array}{l}-0.014 \\
(0.009)\end{array}$ & $\begin{array}{c}0.011 \\
(0.011)\end{array}$ & $\begin{array}{l}-0.019 \\
(0.015)\end{array}$ & $\begin{array}{l}-0.009 \\
(0.021)\end{array}$ & $\begin{array}{l}-0.010 \\
(0.005)\end{array}$ & $\begin{array}{l}-0.007 \\
(0.006)\end{array}$ & $\begin{array}{c}0.006 \\
(0.008)\end{array}$ & $\begin{array}{l}-0.017 \\
(0.012)\end{array}$ & $\begin{array}{l}-0.015 \\
(0.016)\end{array}$ \\
\hline TFP-IND & $\beta$ & $\begin{array}{l}-0.003 \\
(0.005)\end{array}$ & $\begin{array}{c}0.005 \\
(0.007)\end{array}$ & $\begin{array}{c}0.005 \\
(0.010)\end{array}$ & $\begin{array}{c}0.004 \\
(0.014)\end{array}$ & $\begin{array}{l}-0.003 \\
(0.020)\end{array}$ & $\begin{array}{l}-0.005 \\
(0.003)\end{array}$ & $\begin{array}{c}0.004 \\
(0.005)\end{array}$ & $\begin{array}{c}0.003 \\
(0.007)\end{array}$ & $\begin{array}{c}0.007 \\
(0.010)\end{array}$ & $\begin{array}{c}0.000 \\
(0.014)\end{array}$ \\
\hline$\#$ of treatment firms & & 7381 & 2751 & 1484 & 894 & 464 & 7381 & 2751 & 1484 & 894 & 464 \\
\hline \# of control firms & & 6920 & 2635 & 1427 & 861 & 454 & 94577 & 63117 & 42999 & 27998 & 17488 \\
\hline
\end{tabular}

Notes: $\beta$ reports the estimation results using propensity score matching methods. TFP-OP, TFP-EXP, TFP-ENDEXP, and TFP-IND are different measures of TFP following Olley and Pake (1996), De Loecker (2007), De Loecker (2010a), and Klette and Griliches (1996), respectively. The s denotes the stage of exporting with s=0 standing for the first stage of exporting. Bootstrap standard errors are in parentheses. *, **, and *** indicate significance at $10 \%, 5 \%$, and $1 \%$ level, respectively. 
Table 6. Cumulative productivity changes of export entrants with different years of consecutive exporting

\begin{tabular}{|c|c|c|c|c|c|c|}
\hline $\begin{array}{l}\text { Number of years of } \\
\text { consecutive exporting }\end{array}$ & & $\mathrm{s}=0$ & $\mathrm{~s}=1$ & $\mathrm{~s}=2$ & $\mathrm{~s}=3$ & $\mathrm{~s}=4$ \\
\hline \multicolumn{7}{|c|}{ Panel A: Domestic firms } \\
\hline 1 year or above & $\beta$ & $\begin{array}{c}0.008 * * * \\
(0.003)\end{array}$ & & & & \\
\hline 2 years or above & $\beta$ & $\begin{array}{l}0.013 * * * \\
(0.004)\end{array}$ & $\begin{array}{c}0.025 * * * \\
(0.004)\end{array}$ & & & \\
\hline 3 years or above & $\beta$ & $\begin{array}{l}0.013 * * * \\
(0.005)\end{array}$ & $\begin{array}{c}0.025 * * * \\
(0.005)\end{array}$ & $\begin{array}{c}0.035 * * * \\
(0.006)\end{array}$ & & \\
\hline 4 years or above & $\beta$ & $\begin{array}{l}0.012 * \\
(0.006)\end{array}$ & $\begin{array}{c}0.015 * * \\
(0.006)\end{array}$ & $\begin{array}{c}0.027 * * * \\
(0.007)\end{array}$ & $\begin{array}{c}0.030 * * * \\
(0.007)\end{array}$ & \\
\hline 5 years or above & $\beta$ & $\begin{array}{c}0.009 \\
(0.009)\end{array}$ & $\begin{array}{l}0.015 * \\
(0.009)\end{array}$ & $\begin{array}{c}0.020 * * \\
(0.009)\end{array}$ & $\begin{array}{c}0.032 * * * \\
(0.010)\end{array}$ & $\begin{array}{c}0.042 * * * \\
(0.010)\end{array}$ \\
\hline \multicolumn{7}{|c|}{ Panel B: Foreign affiliates } \\
\hline 1 year or above & $\beta$ & $\begin{array}{l}-0.003 \\
(0.005)\end{array}$ & & & & \\
\hline 2 years or above & $\beta$ & $\begin{array}{l}-0.007 \\
(0.006)\end{array}$ & $\begin{array}{c}0.001 \\
(0.006)\end{array}$ & & & \\
\hline 3 years or above & $\beta$ & $\begin{array}{l}-0.008 \\
(0.007)\end{array}$ & $\begin{array}{c}0.002 \\
(0.008)\end{array}$ & $\begin{array}{c}0.011 \\
(0.008)\end{array}$ & & \\
\hline 4 years or above & $\beta$ & $\begin{array}{l}-0.016 * \\
(0.009)\end{array}$ & $\begin{array}{c}0.001 \\
(0.009)\end{array}$ & $\begin{array}{c}0.007 \\
(0.011)\end{array}$ & $\begin{array}{c}0.003 \\
(0.011)\end{array}$ & \\
\hline 5 years or above & $\beta$ & $\begin{array}{l}-0.002 \\
(0.012)\end{array}$ & $\begin{array}{c}0.005 \\
(0.012)\end{array}$ & $\begin{array}{l}0.029 * * \\
(0.013)\end{array}$ & $\begin{array}{c}0.010 \\
(0.015)\end{array}$ & $\begin{array}{c}0.016 \\
(0.015)\end{array}$ \\
\hline
\end{tabular}

Notes: $\beta$ reports the estimation results of TFP-OP using nearest neighbor matching methods. The "s" denotes the stage of exporting with $\mathrm{s}=0$ standing for the first stage of exporting. Bootstrap standard errors are in parentheses. $*{ }^{* *}$, and $* * *$ indicate significance at $10 \%, 5 \%$, and $1 \%$ level, respectively 
Table 7. Cumulative productivity changes of export quitters with different years of consecutive non-exporting

\begin{tabular}{|c|c|c|c|c|c|c|}
\hline $\begin{array}{l}\text { Number of years of } \\
\text { consecutive non-exporting }\end{array}$ & & $\mathrm{s}=0$ & $\mathrm{~s}=1$ & $\mathrm{~s}=2$ & $\mathrm{~s}=3$ & $\mathrm{~s}=4$ \\
\hline \multicolumn{7}{|c|}{ Panel A: Domestic firms } \\
\hline 1 year or above & $\beta$ & $\begin{array}{c}-0.01 * * * \\
(0.003)\end{array}$ & & & & \\
\hline 2 years or above & $\beta$ & $\begin{array}{l}-0.007 * \\
(0.004)\end{array}$ & $\begin{array}{c}-0.014 * * * \\
(0.004)\end{array}$ & & & \\
\hline 3 years or above & $\beta$ & $\begin{array}{l}-0.003 \\
(0.005)\end{array}$ & $\begin{array}{l}-0.011 * \\
(0.006)\end{array}$ & $\begin{array}{l}-0.011 * \\
(0.006)\end{array}$ & & \\
\hline 4 years or above & $\beta$ & $\begin{array}{c}0.003 \\
(0.007)\end{array}$ & $\begin{array}{l}-0.002 \\
(0.007)\end{array}$ & $\begin{array}{l}-0.011 \\
(0.008)\end{array}$ & $\begin{array}{l}-0.009 \\
(0.009)\end{array}$ & \\
\hline 5 years or above & $\beta$ & $\begin{array}{c}0.006 \\
(0.009)\end{array}$ & $\begin{array}{l}-0.007 \\
(0.009)\end{array}$ & $\begin{array}{c}0.001 \\
(0.010)\end{array}$ & $\begin{array}{l}-0.002 \\
(0.011)\end{array}$ & $\begin{array}{l}-0.004 \\
(0.012)\end{array}$ \\
\hline \multicolumn{7}{|c|}{ Panel B: Foreign affiliates } \\
\hline 1 year or above & $\beta$ & $\begin{array}{l}-0.007 \\
(0.005)\end{array}$ & & & & \\
\hline 2 years or above & $\beta$ & $\begin{array}{c}0.005 \\
(0.007)\end{array}$ & $\begin{array}{c}0.009 \\
(0.007)\end{array}$ & & & \\
\hline 3 years or above & $\beta$ & $\begin{array}{c}0.010 \\
(0.009)\end{array}$ & $\begin{array}{l}0.019 * \\
(0.010)\end{array}$ & $\begin{array}{l}0.021 * \\
(0.011)\end{array}$ & & \\
\hline 4 years or above & $\beta$ & $\begin{array}{c}0.018 \\
(0.011)\end{array}$ & $\begin{array}{c}0.018 \\
(0.012)\end{array}$ & $\begin{array}{c}0.014 \\
(0.013)\end{array}$ & $\begin{array}{c}0.013 \\
(0.014)\end{array}$ & \\
\hline 5 years or above & $\beta$ & $\begin{array}{c}0.006 \\
(0.016) \\
\end{array}$ & $\begin{array}{l}-0.021 \\
(0.016) \\
\end{array}$ & $\begin{array}{l}-0.005 \\
(0.017) \\
\end{array}$ & $\begin{array}{l}-0.018 \\
(0.019) \\
\end{array}$ & $\begin{array}{l}-0.017 \\
(0.019) \\
\end{array}$ \\
\hline
\end{tabular}

Notes: $\beta$ reports the estimation results of TFP-OP using nearest neighbor matching method. The "s" denotes the stage of exporting with $s=0$ standing for the first stage of exporting. Bootstrap standard errors are in parentheses. *,**, and *** indicate significance at $10 \%, 5 \%$, and $1 \%$ level, respectively. 
Table 8. Impacts of export entry on productivity for new exporters without exporting history

\begin{tabular}{|c|c|c|c|c|c|c|}
\hline & & $\mathrm{s}=0$ & $\mathrm{~s}=1$ & $\mathrm{~s}=2$ & $s=3$ & $\mathrm{~s}=4$ \\
\hline \multicolumn{7}{|c|}{ Panel A: Domestic firms } \\
\hline \multirow[t]{2}{*}{ TFP-OP } & $\beta$ & $0.006^{* *}$ & $0.021 * * *$ & $0.035 * * *$ & $0.028 * * *$ & $0.028 * *$ \\
\hline & & $(0.003)$ & $(0.005)$ & $(0.006)$ & $(0.008)$ & $(0.011)$ \\
\hline \multirow[t]{2}{*}{ TFP-EXP } & $\beta$ & $0.014 * *$ & $0.024 * * *$ & $0.043 * * *$ & $0.027 * * *$ & $0.027 * *$ \\
\hline & & $(0.003)$ & $(0.005)$ & $(0.006)$ & $(0.008)$ & $(0.011)$ \\
\hline \multirow[t]{2}{*}{ TFP-ENDEXP } & $\beta$ & $0.016 * *$ & $0.027 * * *$ & $0.051 * * *$ & $0.038 * * *$ & $0.042 * * *$ \\
\hline & & $(0.004)$ & $(0.006)$ & $(0.007)$ & $(0.010)$ & $(0.014)$ \\
\hline \multirow[t]{2}{*}{ TFP-IND } & $\beta$ & $0.0011 * *$ & $0.022 * * *$ & $0.033 * * *$ & $0.032 * * *$ & $0.038 * *$ \\
\hline & & $(0.003)$ & $(0.005)$ & $(0.006)$ & $(0.008)$ & $(0.012)$ \\
\hline \multicolumn{2}{|l|}{ \# of treatment firms } & 15118 & 5886 & 3329 & 1924 & 938 \\
\hline \multicolumn{2}{|l|}{ \# of control firms } & 14360 & 5688 & 3197 & 1856 & 935 \\
\hline \multicolumn{7}{|c|}{ Panel B: Foreign firms } \\
\hline \multirow[t]{2}{*}{ TFP-OP } & $\beta$ & -0.009 & -0.007 & 0.008 & -0.004 & 0.006 \\
\hline & & $(0.006)$ & $(0.008)$ & $(0.010)$ & $(0.012)$ & $(0.018)$ \\
\hline \multirow[t]{2}{*}{ TFP-EXP } & $\beta$ & $-0.016 * * *$ & -0.007 & -0.004 & -0.004 & 0.006 \\
\hline & & $(0.006)$ & $(0.008)$ & $(0.010)$ & $(0.013)$ & $(0.018)$ \\
\hline \multirow[t]{2}{*}{ TFP-ENDEXP } & $\beta$ & $-0.018 * * *$ & -0.012 & -0.008 & 0.002 & 0.0018 \\
\hline & & $(0.007)$ & $(0.009)$ & $(0.011)$ & $(0.014)$ & $(0.019)$ \\
\hline \multirow[t]{2}{*}{ TFP-IND } & $\beta$ & $-0.010^{*}$ & -0.000 & 0.009 & 0.004 & 0.015 \\
\hline & & $(0.006)$ & $(0.008)$ & $(0.010)$ & $(0.013)$ & $(0.017)$ \\
\hline \multirow{2}{*}{\multicolumn{2}{|c|}{ \# of treatment firms }} & 5491 & 2857 & 1853 & 1255 & 797 \\
\hline & & 4794 & 2494 & 1579 & 1051 & 652 \\
\hline
\end{tabular}


Table 9. Industry-level productivity gains of domestic exporters

\begin{tabular}{|c|c|c|c|c|}
\hline Two-digit industry & Tech Level & $\begin{array}{l}\text { Immediate } \\
\text { TFP gains }\end{array}$ & $\begin{array}{c}\text { Cumulative } \\
\text { TFP gains }\end{array}$ & $\begin{array}{l}\text { Maximum } \\
\text { TFP gains }\end{array}$ \\
\hline Pharmaceuticals & High & $V_{-}$ & $\sqrt{ }$ & $7.2 \%$ \\
\hline Electronic and Communication Equipment & High & & $\sqrt{ }$ & $4.9 \%$ \\
\hline Chemical Materials and Products & Medium-high & $\sqrt{ }$ & $\sqrt{ }$ & $5.7 \%$ \\
\hline Chemical Fiber & Medium-high & & $\sqrt{ }$ & $6.3 \%$ \\
\hline General Machinery Manufacturing & Medium-high & $\sqrt{ }$ & $\sqrt{ }$ & $5.0 \%$ \\
\hline Special Equipment Manufacturing & Medium-high & $\sqrt{ }$ & $\sqrt{ }$ & $7.1 \%$ \\
\hline Transport Equipment & Medium-high & $\sqrt{ }$ & $\sqrt{ }$ & $6.2 \%$ \\
\hline Electrical Machinery and Apparatus & Medium-high & & $\sqrt{ }$ & $3.4 \%$ \\
\hline Instruments and Meters and Office Machines & Medium-high & $\sqrt{ }$ & $\sqrt{ }$ & $4.5 \%$ \\
\hline Petroleum Processing and Coking & Medium-low & & & - \\
\hline Rubber Products & Medium-low & & $\sqrt{-}$ & $4.9 \%$ \\
\hline Plastics Products & Medium-low & $\sqrt{ }$ & & $6.8 \%$ \\
\hline Non-metallic Mineral Products & Medium-low & & $\sqrt{-}$ & $2.2 \%$ \\
\hline Black Metal Smelting and Processing & Medium-low & $\sqrt{ }$ & $\sqrt{ }$ & $4.5 \%$ \\
\hline Non-ferrous Metal Smelting and Processing & Medium-low & & $\sqrt{ }$ & $3.2 \%$ \\
\hline Metal Products & Medium-low & & $\sqrt{ }$ & $2.6 \%$ \\
\hline Food Processing & Low & & & - \\
\hline Food Production & Low & & & - \\
\hline Beverage Manufacturing & Low & & & - \\
\hline Tobacco Processing & Low & & & - \\
\hline Textile & Low & $V_{-}$ & $\sqrt{ }$ & $5.9 \%$ \\
\hline Apparel and Other Textile Products & Low & & & - \\
\hline Leather, Fur, and Coat Products & Low & & & - \\
\hline Wood Processing, and Other Wood Products & Low & & $\sqrt{-}$ & $6.7 \%$ \\
\hline Furniture & Low & & & - \\
\hline Paper Making and Paper Products & Low & & & - \\
\hline Printing and Recording Media Reproducing & Low & & & - \\
\hline Stationery and Sporting Goods & Low & $\sqrt{ }$ & $\sqrt{ }$ & $5.2 \%$ \\
\hline Other Manufacturing & Low & & & - \\
\hline
\end{tabular}




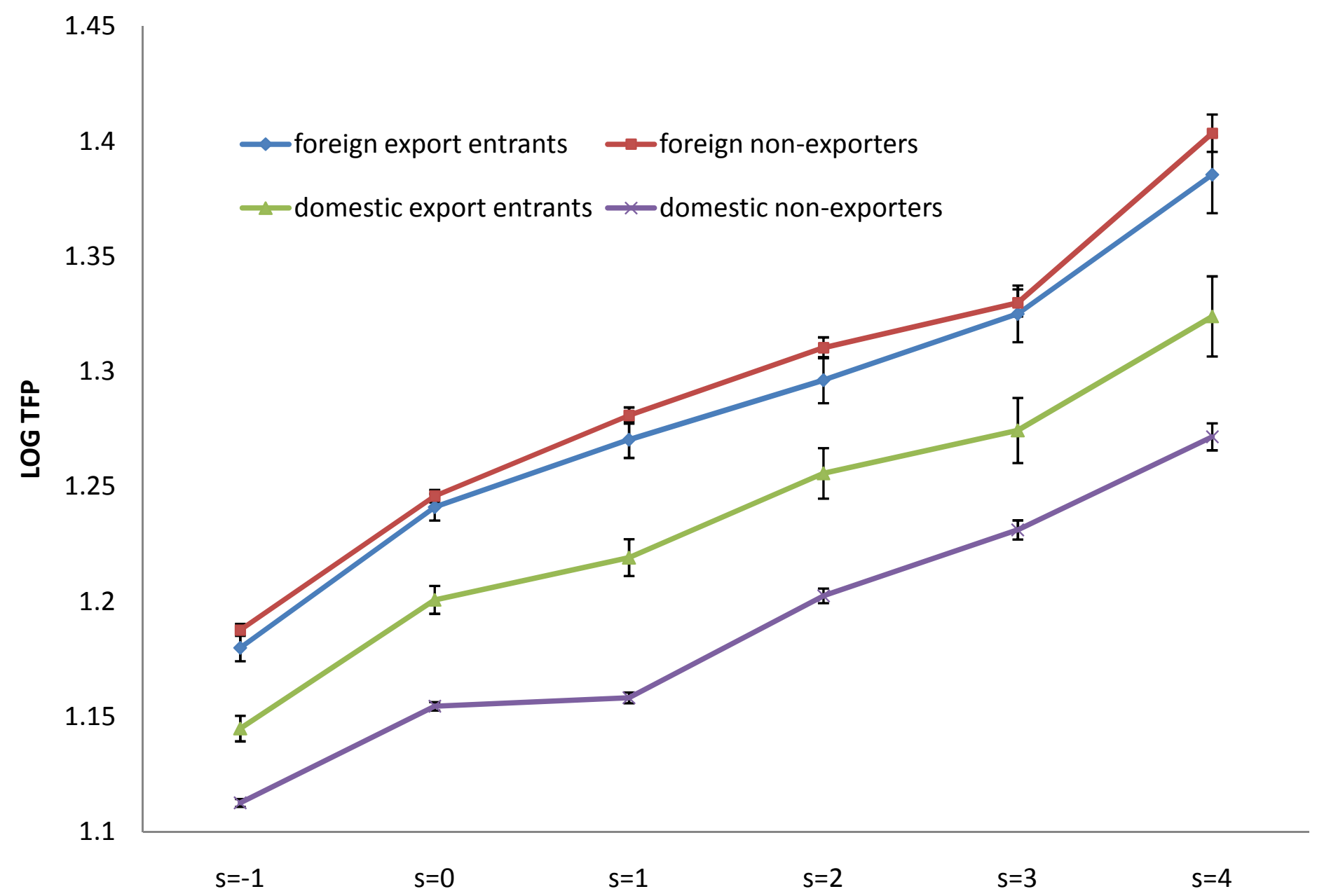

Figure 1. TFP trajectory of export entrants and non-exporters for domestic firms and foreign affiliates (unmatched sample with 95\% cofidence intervals, s denotes the stages of exporting) 


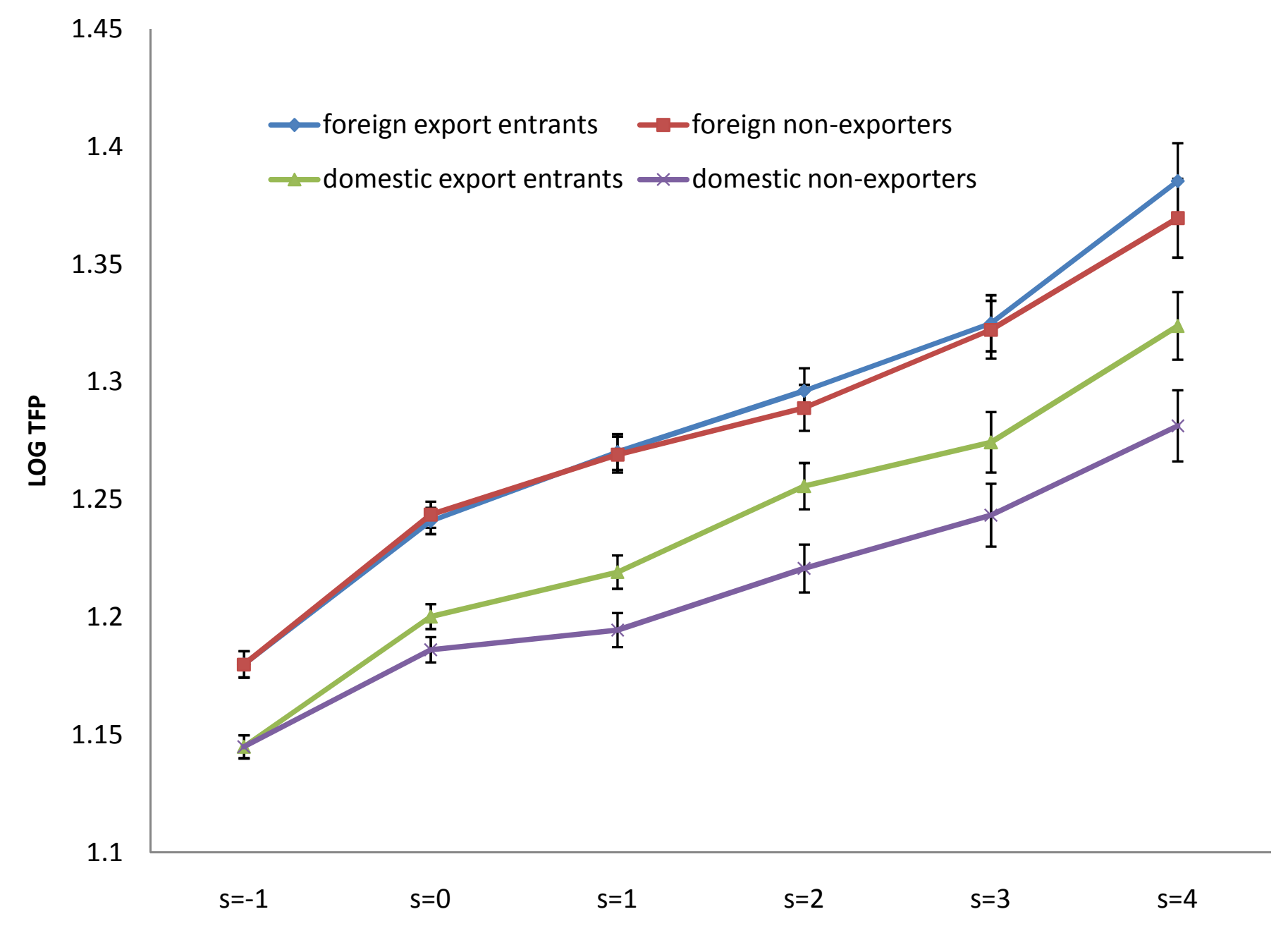

Figure 2. TFP trajectory of export entrants and non-exporters for domestic firms and foreign affiliates (matched sample with $95 \%$ cofidence intervals, $s$ denotes the stages of exporting) 


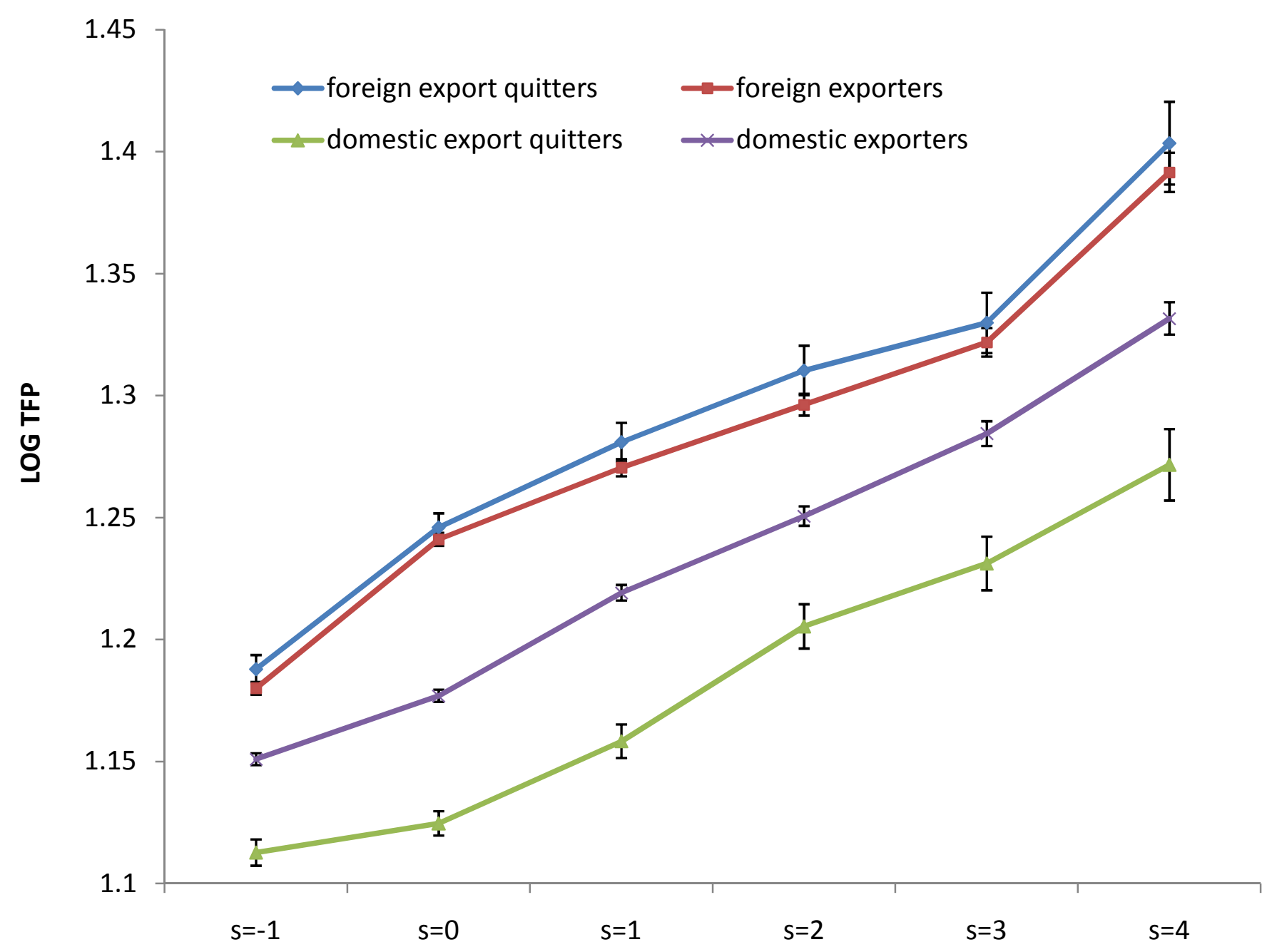

Figure 3. TFP trajectory of export quitters and exporters for domestic firms and foreign affiliates (ummatched sample with $95 \%$ cofidence intervals, $\mathrm{s}$ denotes the stages of non-exporting) 


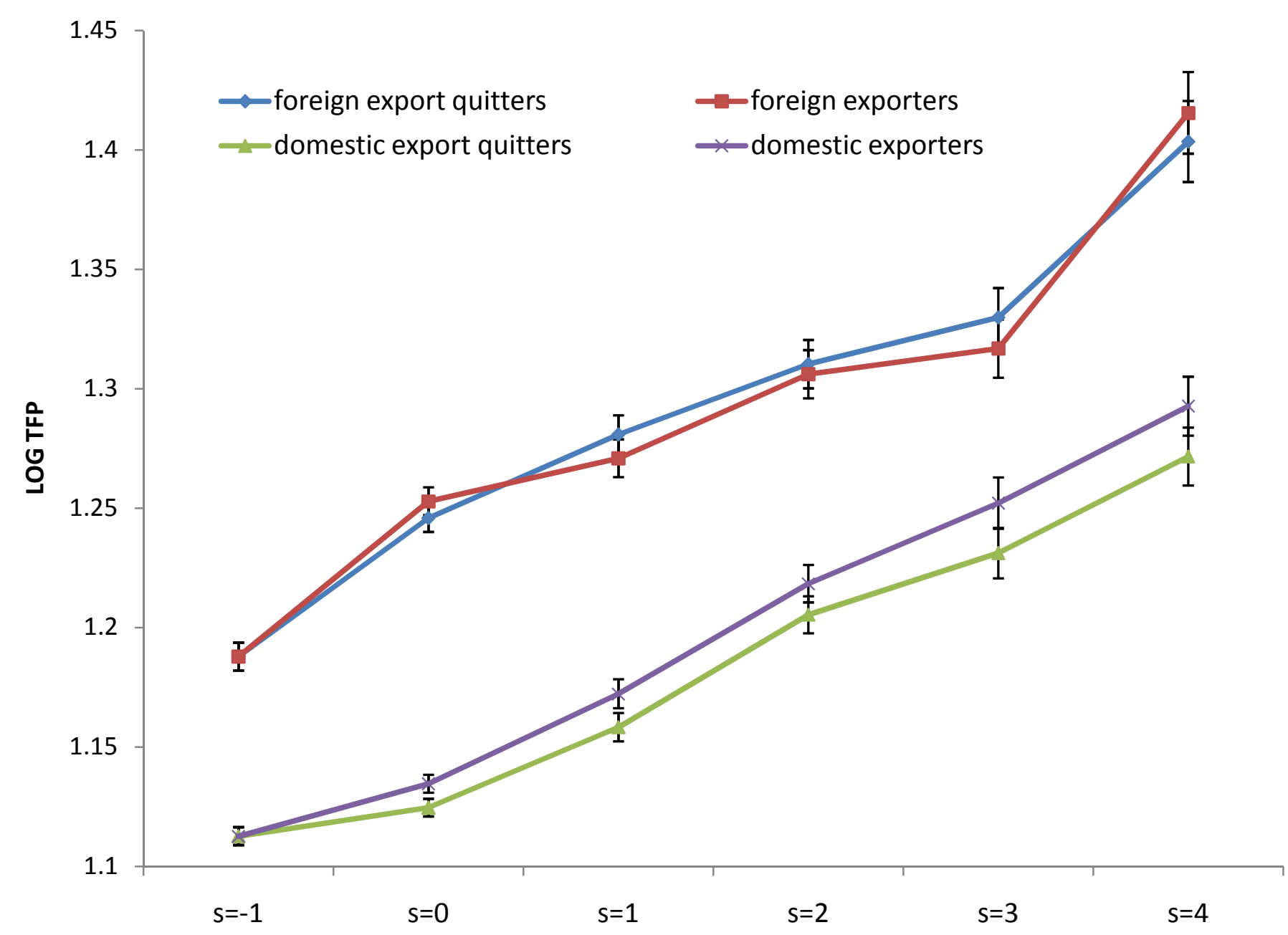

Figure 4. TFP trajectory of export quitters and exporters for domestic firms and foreign affiliates (matched sample with $95 \%$ cofidence intervals, $s$ denotes the stages of non-exporting) 